\title{
Monophyly, Interrelationships and Description of Three New Genera in the Dottyback Fish Subfamily Pseudoplesiopinae (Teleostei: Perciformes: Pseudochromidae)
}

\author{
AnTHONy C. Gill ${ }^{1}$ AND Alasdair J. EdWARds ${ }^{2}$ \\ ${ }^{1}$ Department of Zoology, The Natural History Museum, Cromwell Road, London SW7 5BD, United Kingdom \\ t.gill@nhm.ac.uk \\ ${ }^{2}$ Centre for Tropical and Coastal Management Studies, Department of Marine Sciences and Coastal \\ Management, University of Newcastle, Newcastle upon Tyne NE1 7RU, United Kingdom \\ a.j.edwards@newcastle.ac.uk
}

\begin{abstract}
Within the Pseudochromidae, the subfamily Pseudoplesiopinae is diagnosed by six unequivocal autapomorphies: single tubed lateral-line scale; posterior part of pelvic bone with triangular or hook-shaped lateral process; base of anterior process on pelvic bone posteriorly positioned; coracoid articulates ventrally with medial face of lateral lamina of cleithrum; basihyal bound to anterior face of basibranchial 1; and urohyal with prominent dorsally directed process. Five genera are recognised in the subfamily. Pseudoplesiops Bleeker (Nematochromis Weber is a junior synonym), with seven nominal species, is diagnosed by a single autapomorphy: medial laminae of pelvic bones expanded dorsally. Chlidichthys Smith (Wamizichthys Smith is a junior synonym), with 10 nominal species, is diagnosed by two autapomorphies: lower lip incomplete; and second infraorbital bone absent. Pectinochromis n.gen. (type species Pseudoplesiops lubbocki Edwards \& Randall), with a single nominal species, is diagnosed by five autapomorphies: second dorsal-fin pterygiophore inserting between neural spine 3 and 4; second supraneural bone absent; first dorsal-fin pterygiophore expanded anteriorly; first dorsalfin pterygiophore with lateral processes; and gill rakers relatively numerous. Amsichthys n.gen. (type species Pseudoplesiops knighti Allen), with a single nominal species, is diagnosed by a single autapomorphy: upper preopercular pore usually absent. Lubbockichthys n.gen. (type species Pseudoplesiops multisquamatus Allen), with a single nominal species, is diagnosed by four autapomorphies: scales small; scales cycloid at all stages of ontogeny; some head bones with weakly honeycombed surface; and parietal enclosing dorsal part of supratemporal laterosensory canal. A parsimony analysis of various characters of the laterosensory system, caudal skeleton, dorsal-fin osteology, and fin-ray branching supports the following relationships: (Lubbockichthys ((Amsichthys + Pseudoplesiops) (Chlidichthys + Pectinochromis))).
\end{abstract}

Gill, ANTHONy C., \& Alasdair J. Edwards, 1999. Monophyly, interrelationships and description of three new genera in the dottyback fish subfamily Pseudoplesiopinae (Teleostei: Perciformes: Pseudochromidae). Records of the Australian Museum 51(2): 141-160. 
The Pseudochromidae is a family of small, reef-associated fishes, which are distributed throughout the Indo-Pacific. The family is currently divided into four subfamilies: Anisochrominae, Congrogadinae, Pseudochrominae and Pseudoplesiopinae (Godkin \& Winterbottom, 1985). The objectives of the present paper are to provide evidence for monophyly of the Pseudoplesiopinae, to diagnose its included genera, and to investigate phylogenetic relationships among those genera. Species-level revisions of the genera will be provided in forthcoming papers by the present authors.

\section{Historical review of the systematics of the Pseudoplesiopinae}

Bleeker (1858) described the genus Pseudoplesiops for a new species, $P$. typus, from a single specimen from Goram (= Manawoka), Indonesia. He assigned it to his family Pseudochromides [sic], noting that it fell between Pseudochromis Rüppell and Plesiops Oken (now Plesiopidae) in morphology. He described it as having: dorsal fin with 16 unbranched and nine or 10 branched rays; anal fin with seven unbranched and nine branched rays; pelvic fin with no spine and five rays, the outer two elongate and filiform; palatine teeth absent; scales cycloid; and a single anterodorsal lateral line consisting of inconspicuously pored scales. He later (Bleeker, 1875) reported on an additional specimen of the species from Ambon (actually referable to a new Pseudoplesiops species, which we will describe elsewhere) and included the species as sole member of the Pseudoplesiopini, one of three groupings he recognised within his family "Pseudochromidoïdes." The remaining two groupings were Cichlopini, for Cichlops Müller \& Troschel (= Labracinus Schlegel), Pseudochromis Rüppell, Pseudogramma Bleeker (now in Serranidae), Gramma Poey (now in Grammatidae) and Trachinops Günther (now in Plesiopidae), and Plesiopini for Plesiops Oken and Paraplesiops Bleeker (both now in Plesiopidae).

Günther (1860) assigned Pseudoplesiops to his Pseudochromides, which he treated as a subgroup of the Trachinidae, along with Pseudochromis, Cichlops, Opisthognathus [sic] Cuvier (now Opistognathidae), Notothenia Richardson (now Nototheniidae), Harpagifer Richardson (now Harpagiferidae), Heterostichus Girard (now Clinidae) and Pegetodes Richardson (now Channichthyidae).

Boulenger (1895: 336) listed Pseudoplesiops in the Serranidae and noted that it "appears to combine characters of Callanthias [now in Callanthiidae] and Plesiops." Boulenger did not comment on the position of Pseudochromis and Cichlops in this paper, but later (Boulenger, 1901) placed them and genera now assigned to the Opistognathidae, Malacanthidae and Bathymasteridae in the Pseudochromidae.

Boulenger (1899) apparently overlooked Bleeker's (1858) use of Pseudoplesiops (despite his own 1895 reference to Pseudoplesiops Bleeker) and described Pseudoplesiops as a new genus for a new species of cichlid from the Congo, P. nudiceps. He later (1902) described another new species in the genus from the Congo, $P$. squamiceps. Pellegrin (1904) noted that Pseudoplesiops Boulenger was preoccupied and proposed a replacement name, Nanochromis (often subsequently misspelt Nannochromis).

Regan (1913) classified Pseudoplesiops in its own family, Pseudoplesiopidae, but included Pseudochromis and Cichlops in the Serranidae.

Weber (1913) described a new genus and species, Nematochromis annae, from two syntypes collected in Indonesia during the Siboga Expedition, one from Sarasa Island, Postilon Islands, and the other from Solor Strait. He described the species as having: dorsal and anal fins with two weak spines and mostly undivided, segmented rays, totalling 26-27 and 15 rays, respectively; pelvic fin with a weak spine and three unbranched, segmented rays; and lateral line interrupted, consisting of an anterodorsal series of 30 grooved scales and a midlateral posterior series of 15 grooved scales. He assigned the species to the Pseudochromidae.

Jordan (1923) provided a classification for nominal fish genera. He included only Pseudoplesiops in the Pseudoplesiopidae, retaining Nematochromis in the Pseudochromidae.

Weber \& de Beaufort (1929) reexamined the holotype of Pseudoplesiops typus and modified some of the characters given by Bleeker (1858). Most notably, they reported in the generic diagnosis that the pelvic fin had I,4 rays, the first segmented ray thickened, produced and bifid, but reported in the species diagnosis that all segmented rays are simple, and that the anterior two are thickened and elongate. Weber \& de Beaufort (1929, 1931) generally followed Regan's (1913) classification, but recognised the Pseudochromidinae [sic] as a serranid subfamily containing Nematochromis, Dampieria Castelnau (= Labracinus), Pseudochromis and Pseudogramma.

Berg (1940) also followed Regan's assignment of Pseudoplesiops to its own family, while retaining "pseudochromids" in the Serranidae.

Fowler (1931) recognised three subfamilies within the Pseudochrominae: Pseudogramminae (Pseudogramma); Pseudochrominae (Dampieria, Pseudochromis and Nematochromis); and Pseudoplesiopsinae [sic] (Pseudoplesiops). He later (Fowler, 1934) described two new monotypic pseudoplesiopine genera, Loxopseudochromis and Opsipseudochromis, from the Philippines.

Schultz (1943) described a new species, Pseudoplesiops rosae, from Rose Island, Phoenix Islands. He compared it with $P$. typus and assigned Pseudoplesiops to the Pseudochromidae, along with Pseudochromis, Plesiops, Aporops Schultz (now Serranidae) and Pseudogramma. He later (Schultz, 1953) synonymised Nematochromis with Pseudoplesiops and described an additional two species in the genus, $P$. revellei and $P$. sargenti. He also included acanthoclinids (now assigned to the Plesiopidae; see Mooi, 1993 ) in the Pseudochromidae.

Smith (1953) briefly described a new genus and species, Chlidichthys johnvoelckeri from east Africa. In the following year he reviewed pseudoplesiopsine [sic] fishes from south and east Africa (Smith, 1954). He ignored his 
previous description and described $C$. johnvoelckeri again as a new genus and species, along with another new congener, C. pembae, and a second new genus and species, Wamizichthys bibulus. He also assigned $P$. rosae to Chlidichthys, and, in comparing $C$. pembae with similar species, noted that: "It will not be surprising if a careful examination of Pseudoplesiops typus Bleeker, and of Nematochromis annae Weber, prove them to be one and the same and identical with the above." He excluded Fowler's (1934) Loxopseudochromis and Opsipseudochromis to the Owstoniidae (now considered a synonym of the Cepolidae; see Gill \& Mooi, 1993: 331).

Smith (1954) separated the Pseudoplesiopsinae from the Pseudochrominae, the only other pseudochromid subfamily he recognised, on the basis of the following characters: dorsal- and anal-fin spines weak and flexible (versus strong); most segmented rays in dorsal and anal fins simple (versus mostly or all branched); pelvic fins with a weak spine and three or four simple, segmented rays (versus with a spine and five branched, segmented rays); lateral line reduced to a tubed scale at the shoulder and at most a series of pitted scales along middle of side and peduncle (versus represented by an anterodorsal and a posterolateral series of tubed scales); dorsal and anal fins without basal scaly sheaths (versus with basal scaly sheaths); lower pectoralfin proximal radial abutting against both coracoid and scapula (versus coracoid only); and vertebrae $11+16$ (versus $10+16)$.

Böhlke (1960) recognised three separate families, Pseudochromidae, Anisochromidae and Pseudoplesiopidae, and included Chlidichthys, Nematochromis, Pseudoplesiops and Wamizichthys in the latter.

Norman (1966) included P. typus as sole member of the Pseudoplesiopinae, which he regarded as a subfamily of the Plesiopidae. He recognised the Pseudochrominae as a subfamily of the Serranidae, in which he placed Nematochromis [as well as Pseudochromis, Dampieria, Nesiotes De Vis (= Cypho Myers), Pseudochromichthys (= Plesiops, Plesiopidae; see Mooi, 1996), Pseudocrenilabrus Fowler (now in Cichlidae), Pseudogramma and Gramma].

Lubbock reviewed pseudochromids of the Red Sea and northwestern Indian Ocean (Lubbock, 1975), central Indian Ocean (Lubbock, 1976) and western Indian Ocean (Lubbock, 1977). He recognised a total of nine pseudoplesiopine species in these papers, six of which he described as new. He placed all of the species in Chlidichthys, including the monotypic Wamizichthys.

Springer et al. (1977) synonymised the Anisochromidae with the Pseudochromidae, and proposed that the Anisochromidae and Pseudoplesiopinae were more closely related to each other than either was to the Pseudochrominae. Springer et al. noted that several of Smith's (1954) pseudoplesiopine characters were shared with anisochromines, and were thus synapomorphies of the two subfamilies (fin spine development; reduction in number of pelvic-fin rays; presence of at least one unbranched pelvic-fin ray; absence of scale sheaths on dorsal and anal fins; and absence of tubed scales in posterolateral lateral line). They diagnosed the Pseudoplesiopinae by the following autapomorphies: all segmented pelvic-fin rays simple; segmented dorsal-fin rays mostly simple; single tubed lateral-line scale; ventralmost proximal radial of pectoral fin articulates with coracoid and scapula; and all or almost all medial radials of dorsal- and anal-fin pterygiophores fused to proximal radials.

Edwards \& Randall (1983) placed Chlidichthys in junior synonymy with Pseudoplesiops, and described a distinctive new species from the Red Sea, Pseudoplesiops lubbocki.

Godkin \& Winterbottom (1985) provided evidence for classification of the Congrogadidae, previously placed in the Blennioidei or Trachinoidei, as a subfamily of the Pseudochromidae, and the sister-group of the Anisochrominae; they proposed that the Pseudoplesiopinae is the sister-group of the Anisochrominae + Congrogadinae. In so doing, they noted that all of the synapomorphies proposed by Springer et al. (1977) to unite the Anisochrominae with the Pseudoplesiopinae were also found in the Congrogadinae. They also noted that one of the characters used by Springer et al. to diagnose the Pseudoplesiopinae was also found in the Congrogadinae (all or almost all medial radials of dorsal- and anal-fin pterygiophores fused to proximal radials), and that another was not found universally among pseudoplesiopines (ventralmost proximal radial of pectoral fin articulates with coracoid and scapula). They therefore concluded that only three of the pseudoplesiopine autapomorphies proposed by Springer et al. (1977) were valid: segmented pelvic-fin rays all simple; most segmented dorsal-fin rays simple; and a single tubed lateral-line scale. However, they overlooked that Pseudoplesiops lubbocki Edwards \& Randall (1983) has mostly branched dorsal-fin rays.

Allen (1987) described three new species in the genus Pseudoplesiops: P. multisquamatus, P. knighti, P. howensis. He noted, however, that they exhibited characters that had been traditionally used to separate Chlidichthys from Pseudoplesiops. He therefore regarded the generic assignment of the three species provisional.

Gill et al. (1991) followed Schultz (1953) in placing Nematochromis in synonymy with Pseudoplesiops. They noted that the syntypes of $N$. annae represent two different, and otherwise undescribed, species. They therefore designated a lectotype for $N$. annae, and described the second species, $P$. collare, based on the paralectotype and an additional specimen (holotype) from Flores. They also noted that Schultz's $P$. sargenti is a junior synonym of $P$. typus.

Gill \& Randall (1994) demonstrated monophyly for Chlidichthys (including all of the Red Sea and western and central Indian Ocean species recognised in Lubbock's papers) from synapomorphies associated with lower-lip and cephalic-laterosensory morphology, and described a new species from southern Oman, C. cacatuoides. They noted that Pseudoplesiops lubbocki was not referable to Pseudoplesiops, and that instead it shared some characters with Chlidichthys. They suggested that it should be placed in its own genus. 


\section{Materials and methods}

Phylogenetic analyses were performed using the implicit enumeration option of Hennig86 version 1.5 (Farris, 1988). Character polarity was determined by outgroup comparison. The Anisochrominae + Congrogadinae were used as first outgroup following the scheme of relationships proposed by Godkin \& Winterbottom (1985). Assiculoides desmonotus Gill \& Hutchins and Assiculus punctatus Richardson were used as the second and third outgroups, respectively. Although both of these genera are currently classified in the Pseudochrominae, current evidence indicates that they form successive sister groups to a clade consisting of the Anisochrominae + Congrogadinae + Pseudoplesiopinae (Gill \& Hutchins, 1997: 45).

Nomenclature of head pores follows Winterbottom (1986). When referring to fin rays, the term ray is used in its general sense to include both spinous (azygous, unsegmented, bilaterally fused) and soft rays.

Numerous pseudoplesiopine specimens and radiographs were examined for external (including superficial osteology) and post-cranial axial skeleton characters, respectively. These materials, which represented all known species, will be listed in our forthcoming generic revisions. Similarly, a more extensive listing of pseudochromine and nonpseudochromid specimens will be listed in a forthcoming paper on pseudochromid phylogeny and biogeography by the first author. The following cleared and stained pseudoplesiopine specimens (variously prepared following the methods of Taylor, 1967, Dingerkus \& Uhler, 1977, and Potthoff, 1984) were examined (institutional codes follow Leviton et al., 1985): Amsichthys knighti, AMS I.22612034 (1: 28.3 mm SL), AMS I.21540-046 (3: 19.5-30.4 mm SL), ASIZ uncat. (2: 24.0-27.4 mm SL), USNM 306590 (1: 29.2 mm SL); Chlidichthys sp. 1, ROM uncat. (RW 8815) (2: 33.5-38.1 mm SL); C. auratus, USNM 211780 (2: 37.5-37.8 mm SL); C. bibulus, BPBM 27310 (1: $26.8 \mathrm{~mm}$ SL); C. cacatuoides, BMNH 1994.4.19.1 (1 paratype: 37.2 mm SL); C. inornatus, AMS I.23653-002 (1: 27.9 mm SL), ROM CS857 (3: 30.0-37.0 mm SL); C. johnvoelckeri, CAS 35451 (2: 24.7-37.9 mm SL), ROM uncat. (RW 88-26) (2: 36.2-38.7 mm SL); C. pembae, ROM uncat. (RW 88-15) (2: 21.2-23.3 mm SL); C. rubiceps, USNM 211777 (5: 12.0-15.0 mm SL), BMNH 1999.1.14.18 (1: 27.2 mm SL); Lubbockichthys sp. 1, AMS I.25107-067 (1: 47.3 mm SL); L. sp. 2, AMS I.39406-001 (1: 44.6 mm SL); L. sp. 3, AMS I.39407-001 (1: $37.2 \mathrm{~mm} \mathrm{SL);} \mathrm{L.} \mathrm{multisquamatus,} \mathrm{AMS}$ I.20779-175 (1: 36.3 mm SL); Pectinochromis lubbocki, BPBM 28119 (1 paratype: $35.5 \mathrm{~mm}$ SL); Pseudoplesiops sp. 1, AMS I.20756-014 (1: 25.7 mm SL); P. sp. 2, BMNH 1999.1.14.17 (1: 22.6 mm SL); P. annae, AMS I.21918017 (1: $21.0 \mathrm{~mm}$ SL), USNM 270268 (2: 24.2-29.3 mm SL); P. howensis, AMS I.19755-024 (1: $21.0 \mathrm{~mm} \mathrm{SL);} P$. rosae, AMS I.22582-034 (3: 17.2-22.0 mm SL), BMNH 1999.1.14.14-16 (3: 18.0-21.4 mm SL); P. typus, AMS I.19442-013 (1: $50.6 \mathrm{~mm} \mathrm{SL),} \mathrm{ROM} \mathrm{CS585} \mathrm{(1:} 49.0 \mathrm{~mm}$ SL). Our discussions of the morphology of immediate outgroups are largely based on details provided by Springer et al. (1977), Godkin \& Winterbottom (1985) and Winterbottom $(1986,1996)$, and on the following cleared and stained specimens: ANISOCHROMINAE: Anisochromis kenyae, RUSI 4906 (1: 23.3 mm SL); A. straussi, USNM 215859 (4 paratypes: 19.0-24.0 mm SL), USNM 257761 (1: $8.0 \mathrm{~mm}$ SL). CONGROGADINAE: Blennodesmus scapularis, AMS I.26723-087 (2: 49.7-54.1 mm SL), BMNH uncat. (1: $29.6 \mathrm{~mm} \mathrm{SL})$; Congrogadus spinifer, BMNH 1911.1.4.3-4 (1: c. 122 mm SL); Congrogadus subducens, AMS I.26723-051 (1: 49.3 mm SL), AMS I.26723-052 (1: 18.7 mm SL), AMS I.26723-057 (1: 135.0 mm SL), BMNH 1847.7.21.67-69 (1: c. 147 mm SL); Halidesmus scapularis, BMNH 1933.10.31.1-4 (1: c. 114 mm SL); Haliophis guttatus, BMNH 1951.1.16.606-608 (1: c. 82 mm SL). PSEUdochrominaE: Assiculoides desmonotus, WAM P.30929-008 (2 paratypes: 41.3-46.2 mm SL); Assiculus punctatus, AMS I.13113 (1: $63.0 \mathrm{~mm}$ SL), NTM S.10016-009 (4: 21.7-51.9 mm SL).

\section{Subfamily Pseudoplesiopinae}

Pseudoplesiopini Bleeker, 1875: 4.

Diagnosis. Members of the subfamily are diagnosed by the following synapomorphies: single tubed lateral-line scale (character 1); posterior part of pelvic bone with triangular or hook-shaped lateral process for attachment of slip of hypaxial musculature (character 2); base of anterior process on pelvic bone posteriorly positioned (character 3 ); coracoid articulates ventrally with medial face of lateral lamina of cleithrum (character 4); basihyal bound to anterior face of basibranchial 1 (character 5); urohyal with prominent dorsally directed process (character 6). Two additional characters provide equivocal support for monophyly of the subfamily: dorsal profile of anterior ceratohyal straight, without excavation (remnant of beryciform foramen, sensu McAllister, 1968); and all medial radials of dorsaland anal-fin pterygiophores fused to proximal radials. Both characters also occur in the Congrogadinae, but not in the Anisochrominae, their sister group. Therefore, they may be independent autapomorphies of the Congrogadinae and Pseudoplesiopinae, or they may be synapomorphies of the more inclusive Anisochrominae + Congrogadinae + Pseudoplesiopinae clade that have undergone "reversal" in the Anisochrominae. These two characters will be discussed in greater detail in a forthcoming paper on pseudochromid intrarelationships and biogeography by the first author.

\section{Diagnoses of pseudoplesiopine genera}

\section{Lubbockichthys n.gen.}

Figs. 1, 9A, 10A, 12A, 13A, 14A

Type species. Pseudoplesiops multisquamatus Allen, 1987.

Diagnosis. Lubbockichthys is distinguished from other pseudoplesiopines by the following four autapomorphies: parietal enclosing dorsal part of supratemporal laterosensory canal (character 7; also occurs homoplastically in Pseudoplesiops howensis); scales cycloid at all stages of ontogeny (character 8); scales small, scales in lateral series 51-66 (character 9); and some head bones with weakly honeycombed surface (character 10). Two other characters provide equivocal support for monophyly of the genus (see 


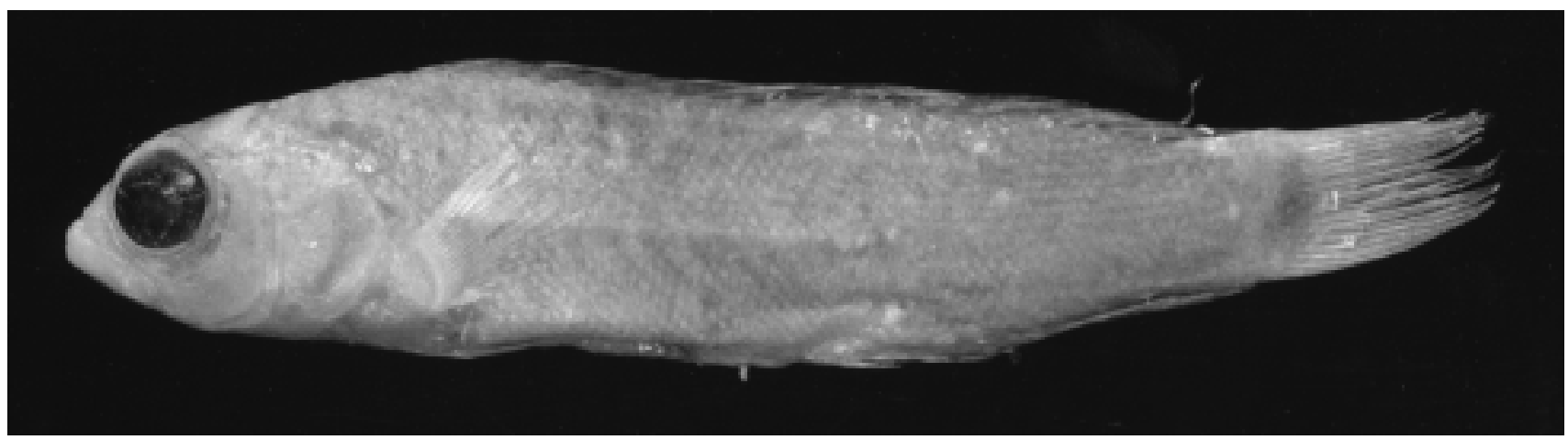

Figure 1. Lubbockichthys multisquamatus, WAM P.27470-002, $41.7 \mathrm{~mm} \mathrm{SL}$, holotype, Escape Reef, Great Barrier Reef.

Results of Parsimony Analysis below). The first of these, posterior interorbital pore present (character 23, state 0 ), is either an autapomorphy of Lubbockichthys, or diagnoses (state 1) a clade consisting of Chlidichthys, Amsichthys, Pectinochromis and Pseudoplesiops. The second character, dorsal-fin rays mostly branched (character 31 , state 1), has three equally parsimonious optimisations on the proposed phylogeny, one of which optimises mostly branched rays as an autapomorphy of Lubbockichthys (and homoplastically of Pectinochromis). Other characters useful in identifying Lubbockichthys are summarised in Table 2.

Included nominal species. Pseudoplesiops multisquamatus Allen, 1987.

Geographic distribution. Eastern Indian Ocean to the central Pacific, from the Cocos-Keeling Islands, east to the Line Islands, south to New Caledonia and north to the Ryukyu Islands.

Justification for erection of new genus. Erection of Lubbockichthys is justified because it establishes a monophyletic classification; species assigned to Lubbockichthys cannot be assigned to any other pseudoplesiopine genus without rendering that genus para- or polyphyletic. The erection of Lubbockichthys also draws attention to the morphological distinctiveness of the genus (and thus acknowledges a morphological gap).

Etymology. Named for the late Dr Hugh Roger Lubbock, in combination with the Greek ichthys, meaning fish, in recognition of Dr Lubbock's contributions to the systematics of pseudochromid fishes. Gender is masculine.

\section{Pseudoplesiops Bleeker}

Figs. 2, 9B, 10B, 11B, 12B, 13B, 14B

Pseudoplesiops Bleeker, 1858: 215 (type species, Pseudoplesiops typus Bleeker, by monotypy).

Nematochromis Weber, 1913: 264 (type species, Nematochromis annae Weber, by monotypy).

Diagnosis. Pseudoplesiops is demonstrably monophyletic in having the medial laminae of the pelvic bones expanded dorsally (character 11). Other characters useful in identifying the genus are summarised in Table 2.

Included nominal species. Nematochromis annae Weber, 1913; Pseudoplesiops collare Gill, Randall \& Edwards, 1991; P. howensis Allen, 1987; P. revellei Schultz, 1953; P.

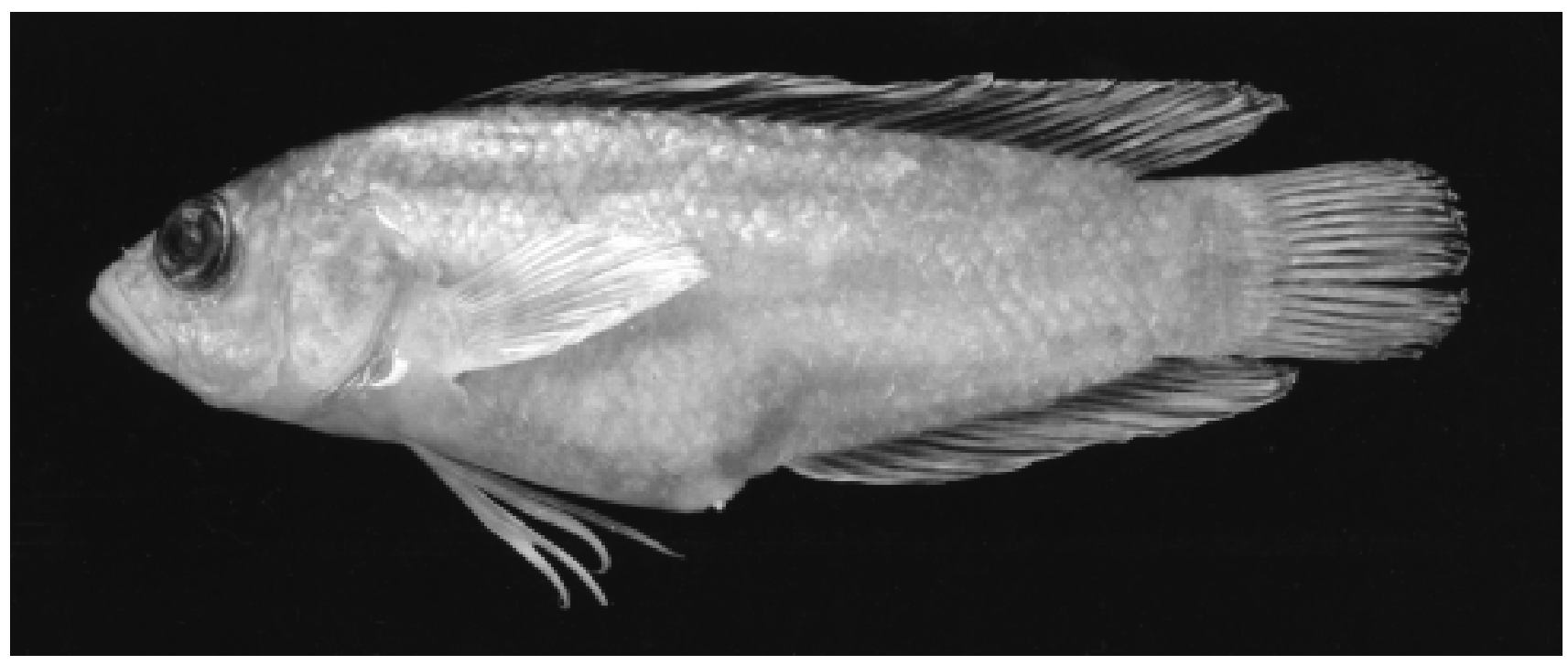

Figure 2. Pseudoplesiops typus, WAM P.30842-019, 54.6 mm SL, Ashmore Reef, Timor Sea. 
rosae Schultz, 1943; P. sargenti Schultz, 1953; P. typus Bleeker, 1858.

Geographic distribution. Central Indian Ocean to the central Pacific, from the Maldive Islands, east to Oeno Atoll, north to the Ryukyu Islands and south to Lord Howe Island.

Etymology. From the Greek pseudos, false, and Plesiops, a genus of plesiopid fish, alluding to the purported similarity between the type species, P. typus, and Plesiops. Gender is masculine.

\section{Amsichthys n.gen.}

Figs. 3, 9C, 10C, 11A, 12C, 13C, 14C

Type species. Pseudoplesiops knighti Allen, 1987.

Diagnosis. Amsichthys is demonstrably monophyletic in lacking the upper preopercular pore (character 12). Monophyly of the genus is also supported by a single homoplastic character that also occurs in Pectinochromis: eyes large (character 30; see Results of Parsimony Analysis below). Other characters useful in identifying the genus are summarised in Table 2.

Included nominal species. Pseudoplesiops knighti Allen, 1987.

Geographic distribution. Eastern Indian Ocean and West Pacific, from the west coast of Thailand, east to the Solomon Islands, south to the Great Barrier Reef and north to the Ryukyu Islands.

Justification for erection of new genus. Our current hypothesis of generic relationships of pseudoplesiopines places Amsichthys as the sister group of Pseudoplesiops. Thus, it could be included within Pseudoplesiops without affecting the monophyletic status of that genus. However, we believe that character evidence for a sister relationship between the two genera is weak; such a relationship is supported by a single character, third supraneural bone well developed (character 25, state 1), but this varies among Pseudoplesiops species and intraspecifically in a Chlidichthys species (see Results of Parsimony Analysis). It is possible that additional characters might lead to a different phylogenetic position for Amsichthys; indeed, a different interpretation of characters 12 and 28 , such that the reduction in number of preopercular pores was seen as homologous, would lead to Chlidichthys + Pectinochromis forming the sister of Amsichthys. We therefore believe that the erection of Amsichthys will ultimately lead to greater nomenclatural stability, as its placement as the sister to any other pseudoplesiopine genus or clade of genera will not affect the generic assignment of its constituent species.

Erection of Amsichthys is also partly justified on the basis of its morphological distinctiveness.

Etymology. The generic name is a combination of AMS, the standard institutional code in ichthyology for the Australian Museum, Sydney, and the Greek ichthys, fish. It acknowledges the generous help, encouragement and friendship given by staff of the Australian Museum's Ichthyology Section to the first author during this study and throughout his career and training. Gender is masculine.

\section{Chlidichthys Smith}

Figs. 4, 6B, 7B, 8B, 9D, 10D, 12D, 13D, 14D

Chlidichthys Smith, 1953: 518 (type species: Chlidichthys johnvoelckeri Smith, 1953, by monotypy).

Wamizichthys Smith, 1954: 205 (type species: Wamizichthys bibulus Smith, 1954, by original designation and monotypy).

Diagnosis. Chlidichthys is distinguished from other pseudoplesiopines and demonstrably monophyletic in having two autapomorphies: lower lip interrupted at symphysis (character 13); and second infraorbital bone absent (character 26, state 2). Two other characters, 31 (state 0 ; mostly unbranched dorsal-fin rays) and 32 (state 1 ; mostly unbranched anal-fin rays), provide equivocal support for monophyly of the genus (see Results of Parsimony Analysis below). Other characters useful in identifying the genus are summarised in Table 2.

Included nominal species. Chlidichthys abruptus Lubbock, 1977; C. auratus Lubbock, 1975; Wamizichthys bibulus Smith, 1954; C. cacatuoides Gill \& Randall, 1994; C. inornatus Lubbock, 1976; C. johnvoelckeri Smith, 1953;

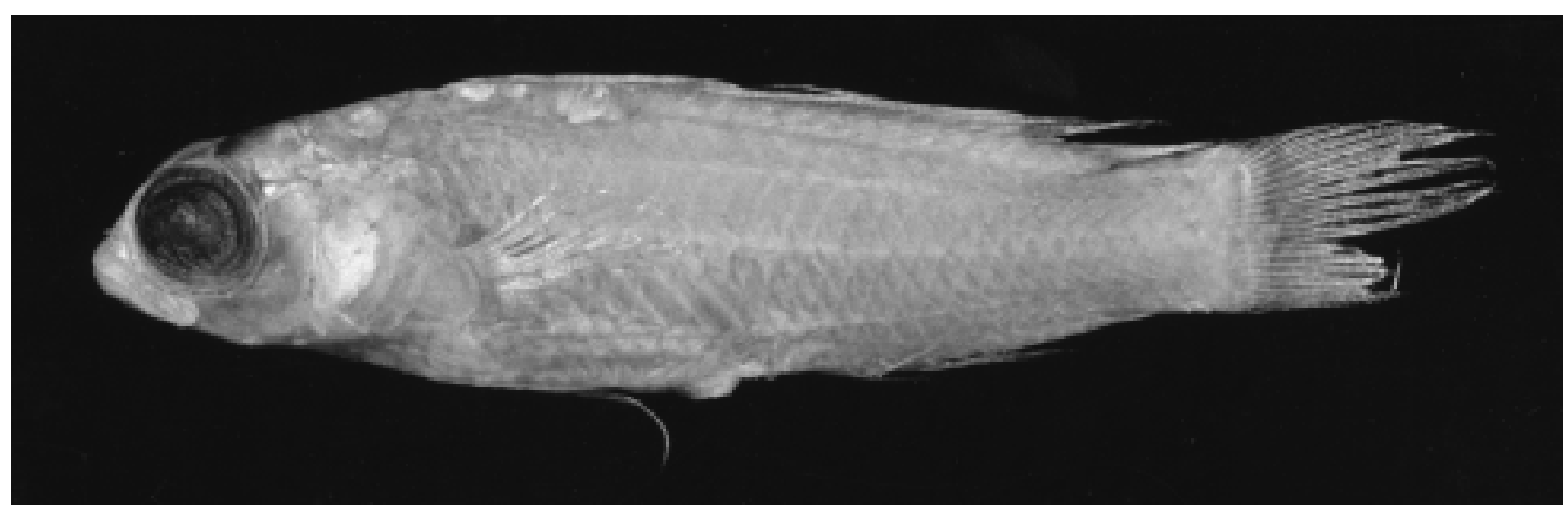

Figure 3. Amsichthys knighti, NTM S.11384-018, North Reef, Timor Sea. 


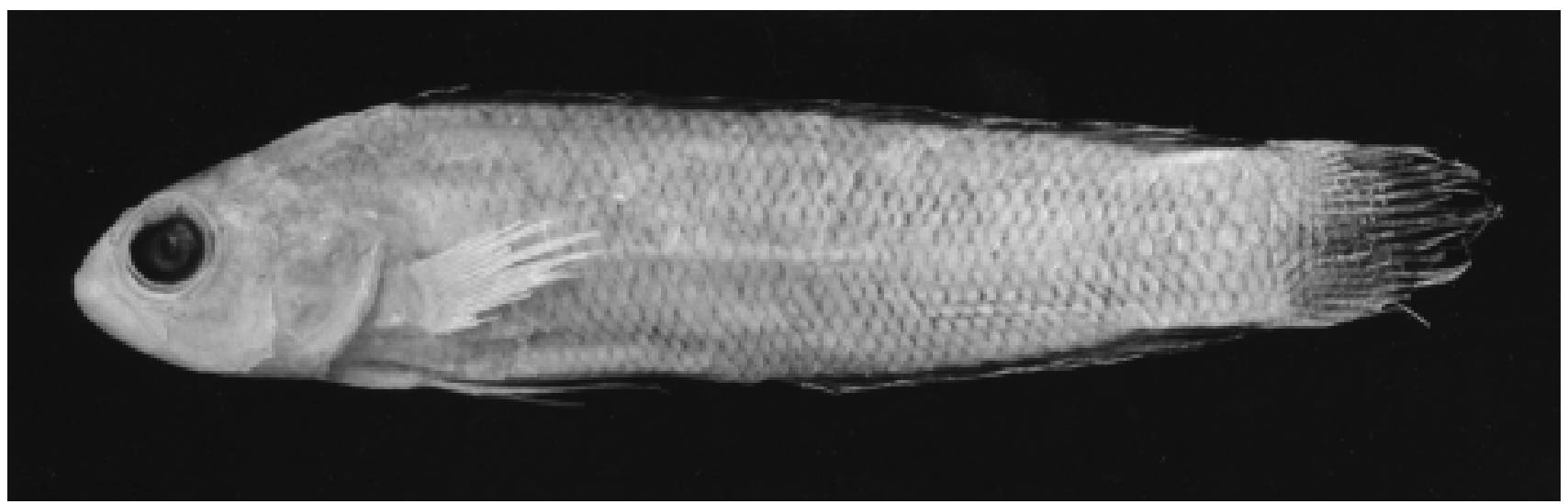

Figure 4. Chlidichthys johnvoelckeri, CAS 35451, 45.7 mm SL, Grande Comore Island, Comoro Islands.

C. pembae Smith, 1954; C. randalli Lubbock, 1977; C. rubiceps Lubbock, 1975; C. smithae Lubbock, 1977.

Geographic distribution. Western Indian Ocean, from the northern Red Sea and east Africa, north to southern Oman, east to Sri Lanka and south to Natal, South Africa.

Etymology. Apparently from the Greek chlidanos, delicate or luxurious, and ichthys, fish. Gender is masculine.

\section{Pectinochromis n.gen.}

Figs. 5, 9E, 10E, 12E, 13E, 14E

Type species. Pseudoplesiops lubbocki Edwards \& Randall, 1983.

Diagnosis. Pectinochromis is distinguished from other pseudoplesiopine genera and demonstrably monophyletic in having six autapomorphies: first dorsal-fin pterygiophore expanded anteriorly (character 14); first dorsal-fin pterygiophore with lateral processes (character 15); second pterygiophore of dorsal fin inserts between neural spines 3 and 4 (character 16); dorsal fin anteriorly positioned (character 17); single supraneural bone (character 18); gill rakers relatively numerous (character 19). Monophyly of the genus is also supported by a single homoplastic character, eyes large (character 30), that also occurs in Amsichthys. Another homoplastic character, dorsal-fin rays mostly branched (character 31, state 1), has three equally parsimonious character optimisations within the Pseudoplesiopinae; two of the optimisations identify it as an autapomorphy of Pectinochromis. The presence of mostly branched anal-fin rays (character 32) also provides equivocal support for monophyly of the genus (see Results of Parsimony Analysis below for discussion of this and the previous two characters). Other characters useful in identifying the genus are summarised in Table 2.

Included nominal species. Pseudoplesiops lubbocki Edwards \& Randall, 1983.

Geographic distribution. Red Sea.

Justification for erection of new genus. Our current hypothesis of generic relationships of pseudoplesiopines places Pectinochromis as the sister group of Chlidichthys; this relationship is strongly supported by five synapomorphies (see Results of Parsimony Analysis below). Thus, Pectinochromis could be included within Chlidichthys without affecting the monophyletic status of that genus. However, our decision to erect Pectinochromis is to draw attention to the morphological distinctiveness of the two genera. Pectinochromis is particularly distinctive, and is readily distinguished from all other pseudochromids by its unusual dorsal-fin and gill-raker morphology.

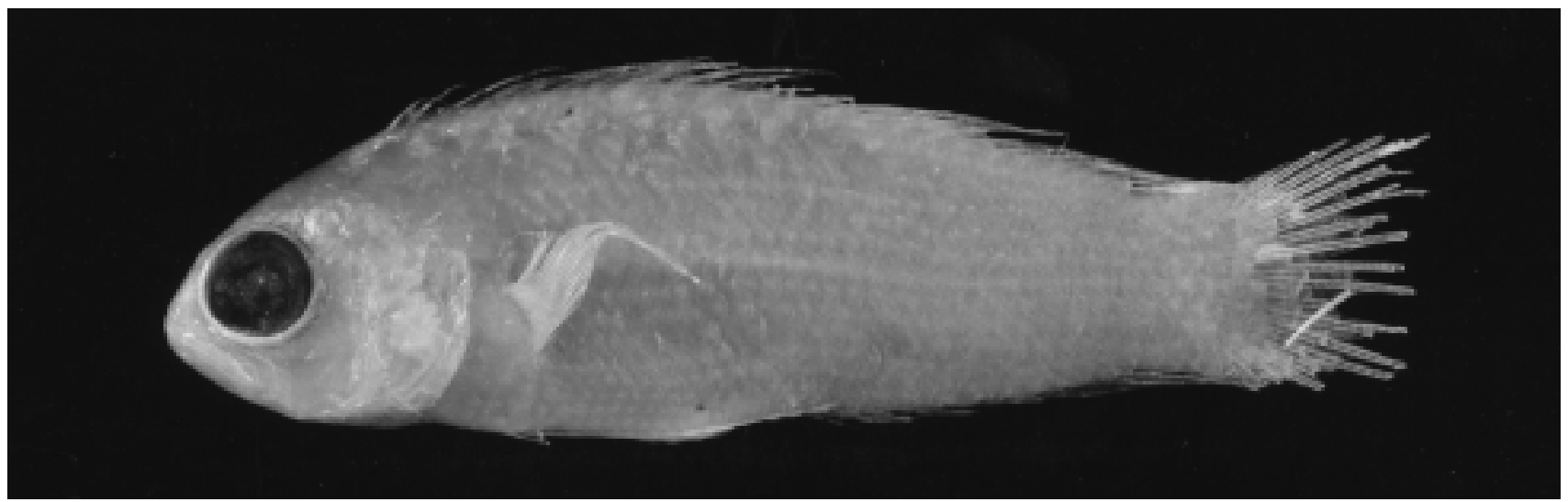

Figure 5. Pectinochromis lubbocki, BMNH 1982.6.9.1-4, 32.2 mm SL, Gulf of Aqaba, Red Sea. 
Table 1. Matrix of 32 characters of pseudoplesiopine genera (see text for details of characters).

character number

\begin{tabular}{|c|c|c|c|c|c|c|c|}
\hline & 12345 & $\begin{array}{rrr} & & 1 \\
6789 & 0\end{array}$ & 12345 & 67890 & 12345 & $67890^{3}$ & 12 \\
\hline outgroup & $\begin{array}{lllllll}0 & 0 & 0 & 0 & 0\end{array}$ & $\begin{array}{lllllll}0 & 0 & 0 & 0 & 0\end{array}$ & ? 000000 & $\begin{array}{lllllllll}0 & 0 & 0 & 0 & 0\end{array}$ & $\begin{array}{llllll}0 & 0 & ? & 0 & 0\end{array}$ & $\begin{array}{lllllll}0 & 0 & 0 & 0 & 0\end{array}$ & $? 0$ \\
\hline Lubbockichthys & $\begin{array}{lllll}1 & 1 & 1 & 1 & 1\end{array}$ & $\begin{array}{lllll}1 & 1 & 1 & 1 & 1\end{array}$ & $\begin{array}{lllllll}0 & 0 & 0 & 0 & 0\end{array}$ & $\begin{array}{llllll}0 & 0 & 0 & 0 & 0\end{array}$ & $\begin{array}{lllllll}0 & 0 & 0 & 0 & 0\end{array}$ & $\begin{array}{lllllllll}0 & 0 & 0 & 0 & 0\end{array}$ & 10 \\
\hline Pseudoplesiops & $\begin{array}{lllll}1 & 1 & 1 & 1 & 1\end{array}$ & $\begin{array}{lllll}1 & 0 & 0 & 0 & 0\end{array}$ & 100000 & $\begin{array}{llllll}0 & 0 & 0 & 0 & 1\end{array}$ & 111110 & $\begin{array}{llllll}0 & 0 & 0 & 0 & 0\end{array}$ & 01 \\
\hline Amsichthys & $\begin{array}{lllll}1 & 1 & 1 & 1 & 1\end{array}$ & 10000 & $\begin{array}{llllll}0 & 1 & 0 & 0 & 0\end{array}$ & $\begin{array}{lllll}0 & 0 & 0 & 0 & 1\end{array}$ & 11110 & $\begin{array}{lllll}0 & 0 & 0 & 0 & 1\end{array}$ & 01 \\
\hline Chlidichthys & $\begin{array}{lllll}1 & 1 & 1 & 1 & 1\end{array}$ & 10000 & $\begin{array}{llllll}0 & 0 & 1 & 0 & 0\end{array}$ & $\begin{array}{lllll}0 & 0 & 0 & 0 & 1\end{array}$ & $\begin{array}{lllll}11 & 1 & 0 & 1\end{array}$ & 21110 & 01 \\
\hline Pectinochromis & $\begin{array}{lllll}11 & 1 & 1 & 1\end{array}$ & 10000 & $\begin{array}{llllll}0 & 0 & 0 & 1 & 1\end{array}$ & $\begin{array}{lllll}1 & 1 & 1 & 1 & 1\end{array}$ & $\begin{array}{lllll}11 & 1 & 0 & 1\end{array}$ & $\begin{array}{lllll}11 & 1 & 1 & 1\end{array}$ & 10 \\
\hline
\end{tabular}

Etymology. The generic name is from the Latin pecten, a comb or rake, and the Greek Chromis, a genus of pomacentrid fish, which has been used as a suffix for various pseudochromid genera (e.g., Pseudochromis and Nematochromis), and alludes to the relatively high number of gill rakers. Gender is feminine, in keeping with the accepted gender of Chromis [see Opinion 1417 (International Commission on Zoological Nomenclature, 1986) for ruling on the gender of Chromis].

\section{Phylogenetic relationships}

Character descriptions. A summary of character state distributions is given in Table 1 .

Character 1. Single tubed anterior lateral-line scale. Pseudochromines and anisochromines have a series of tubed scales in the anterior portion of the lateral line (state 0 ). Pseudoplesiopines usually have only a single tubed scale, which is situated near the branchial opening (state 1; occasional specimens of Lubbockichthys species may have two tubed scales on one or both sides of the body). Congrogadines vary somewhat in the structure of their lateral line, but most have a single, anterodorsal lateral line consisting of a series of tubed scales (exceptions are Rusichthys, which lacks a lateral line, Halidesmus, which has three lateral lines, and Halimuraenoides, some Halimuraena species, one Haliophis species and occasional specimens of some Congrogadus species, all of which have two lateral lines, one anterodorsal, the other midlateral). The state found in pseudoplesiopines is regarded as apomorphic.

Character 2. Posterior part of pelvic bone with triangular or hook-shaped lateral process. Pseudochromines, anisochromines and congrogadines lack lateral processes on the posterior part of the pelvic bone (state 0; Fig. 6A). Pseudoplesiopines have a triangular or hook-shaped lateral process on the posterior part of the pelvic bone, which serves as an attachment site for a slip of hypaxial musculature (state 1; Fig. 6B). This arrangement is regarded as apomorphic.

Character 3. Base of anterior process on pelvic bone posteriorly positioned. The base of the anterior process (sensu Stiassny \& Moore, 1992) of the pelvic bone of pseudochromines and anisochromines is positioned slightly to well anterior to the anterior edge of the pelvic-fin spine base (Fig. 6A; state 0). Congrogadines examined by us lack an anterior process on the pelvic bone. In pseudoplesiopines, the anterior process is positioned noticeably posterior to the anterior edge of pelvic-fin spine base (Fig. 6B; state 1). The latter state is regarded as apomorphic.

Character 4. Coracoid articulates ventrally with medial face of lateral lamina of cleithrum. In pseudochromines, anisochromines and congrogadines the ventral process of the coracoid attaches to the lateral face of a medial lamina on the cleithrum (Fig. 7A; state 0), whereas in pseudoplesiopines the coracoid attaches to the medial face of a lateral lamina (Fig. $7 \mathrm{~B}$; state 1). The latter state is regarded as apomorphic.

Character 5. Basihyal bound to anterior face of basibranchial 1. The basihyal loosely overlies basibranchial 1 in pseudochromines and anisochromines (Fig. 8A,C; state 0). It is tightly bound by connective tissue to the anterior face of basibranchial 1 in pseudoplesiopines (Fig. 8B; state 1). The basihyal is bound more-or-less tightly to basibranchial 1 in congrogadines (Fig. 8D), but the arrangement does not appear to be homologous with the condition found in pseudoplesiopines. Most notably, the condition in congrogadines differs in that there are two articulation points between the two bones, a dorsal attachment between the mid-dorsal face of basibranchial 1 and the posterior tip of the basihyal, and a ventral attachment between the anterior (cartilaginous) tip of basibranchial 1 and the posteroventral edge of the basihyal. In the latter attachment, the basihyal is embraced by small lateral projections that extend anteriorly from basibranchial 1 (and obscure the anterior cartilage tip from lateral view). The congrogadine condition is associated with a very different arrangement of the basibranchial 1/urohyal articulation, where the urohyal is positioned farther posteriorly (as it is also in anisochromines), articulating with a posteroventral process from basibranchial 1 (versus weakly associated with the anterior cartilage tip of basibranchial 1 in pseudochromines and pseudoplesiopines). We consider the basihyal/basibranchial 1 arrangement displayed by pseudoplesiopines to be apomorphic within the Pseudochromidae.

Character 6. Urohyal with prominent dorsally directed process. The urohyal of pseudochromines has a small to moderately developed posterodorsally directed process, which is weakly embraced by anteroventrally projecting processes from the hypobranchials 1 (Fig. 8A; state 0). 

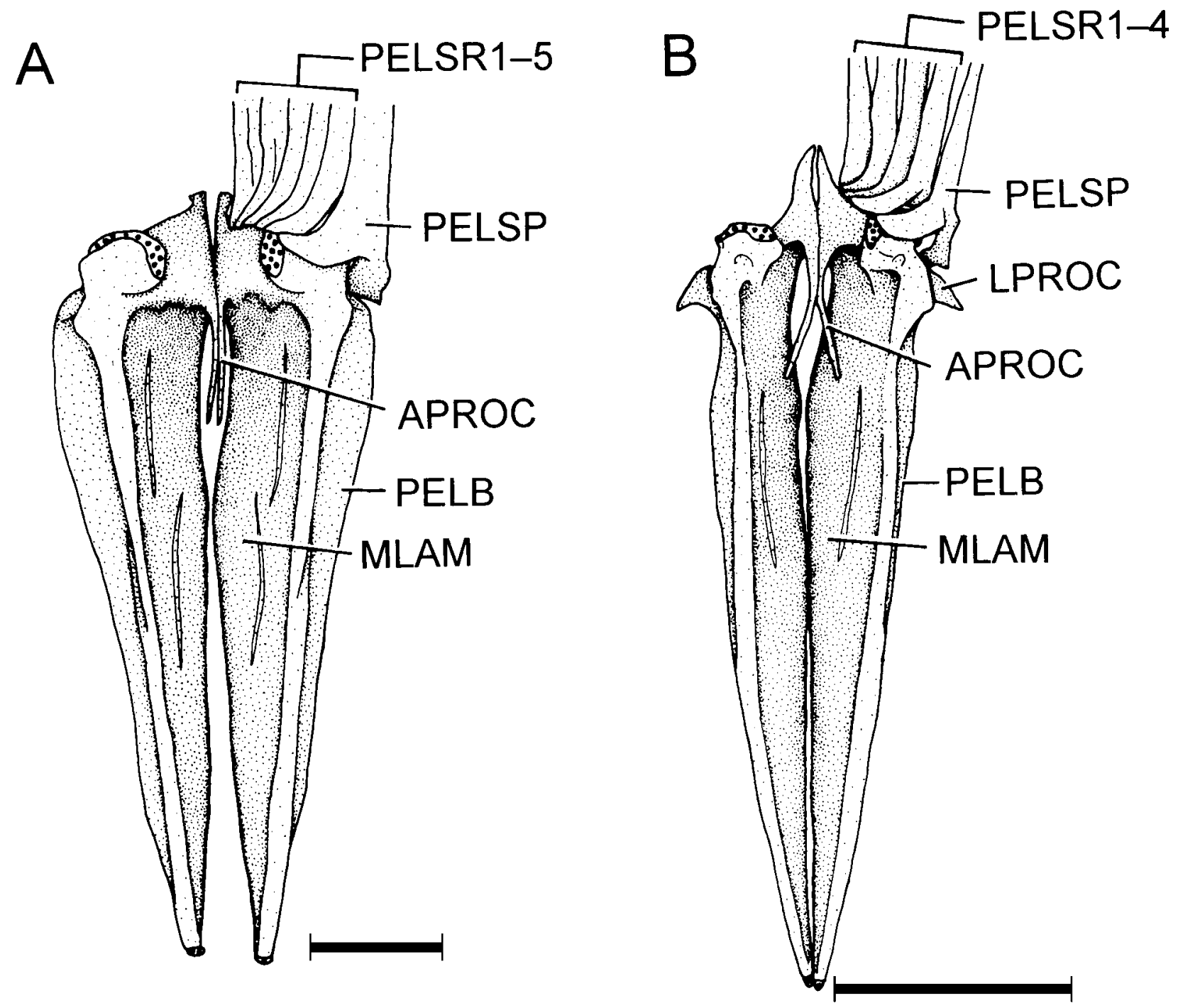

Figure 6. Pelvic girdles of two pseudochromid species in ventral view: A, "Pseudochromis" cf. paccagnellae (Pseudochrominae), AMS I.22613-008, $46.2 \mathrm{~mm}$ SL; B, Chlidichthys johnvoelckeri (Pseudoplesiopinae), CAS $35451,37.9 \mathrm{~mm}$ SL. Anterior to bottom of page; cartilage shown in large stipple. Abbreviations: APROC, anterior process; LPROC, lateral process; MLAM, medial lamina; PELB, pelvic bone; PELSP, pelvic-fin spine; PELSR15 , pelvic segmented rays $1-5$. Scale bars $=1 \mathrm{~mm}$.

Pseudoplesiopines have a prominent dorsal process on the urohyal, which is also embraced by anteroventral processes from the hypobranchials 1 , but it is dorsally rather than posterodorsally directed (Fig. 8B; state 1). Anisochromines and congrogadines lack a dorsal process from the urohyal to the hypobranchials 1 ; the urohyal is well separated from the hypobranchials, and the hypobranchials have small posteroventrally (rather than anteroventrally) projecting processes (Fig. 8C,D). The condition shown by pseudoplesiopines is considered apomorphic within the Pseudochromidae.

Character 7. Parietal bears enclosed lateral-line canal. In Chlidichthys, Amsichthys, Pectinochromis and most Pseudoplesiops, the dorsal portion of the supratemporal lateral-line commissure passes over the parietal as a membranous canal, which is either unossified or ossified medially only (Fig. 9B-E; state 0). In Lubbockichthys and
Pseudoplesiops howensis, the dorsal portion of the supratemporal lateral-line commissure passes through a fully ossified (enclosed) canal in the parietal (Fig. 9A; state 1). In Assiculoides and Assiculus, the supratemporal commissure passes over the parietal in a membranous tube that is either unossified or medially ossified only; anisochromines have similar ossification of the canal, but the commissure is heavily branched and continuous across the dorsal midline. In congrogadines, the commissure is also continuous across the dorsal midline, but is mostly ossified throughout its length. As far as we can ascertain, the ossified portion is separate from, though closely applied to, the parietal bone. We therefore consider the condition shown by Lubbockichthys and P. howensis apomorphic.

Character 8. Scales "cycloid" at all stages of ontogeny. Chlidichthys, Amsichthys, Pectinochromis and Pseudoplesiops have cteni on posterior body scales, at 

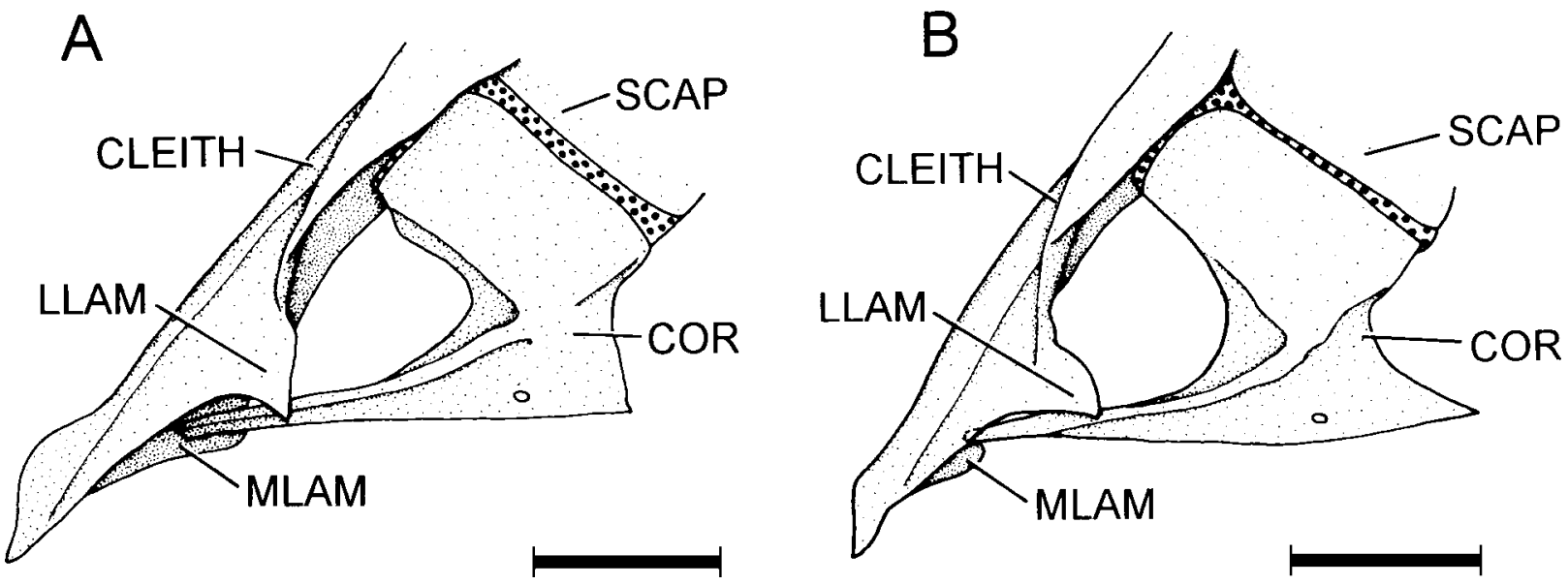

Figure 7. Right lateral view (reversed) of lower part of pectoral girdle of two pseudochromid species: A, "Pseudochromis" diadema (Pseudochrominae), USNM 210017, $35.0 \mathrm{~mm}$ SL; B, Chlidichthys johnvoelckeri (Pseudoplesiopinae), CAS 35451, 37.9 mm SL. Abbreviations: CLEITH, cleithrum; COR, coracoid; MLAM, medial lamina of cleithrum; LLAM, lateral lamina of cleithrum; SCAP, scapula. Scale bars $=1 \mathrm{~mm}$.

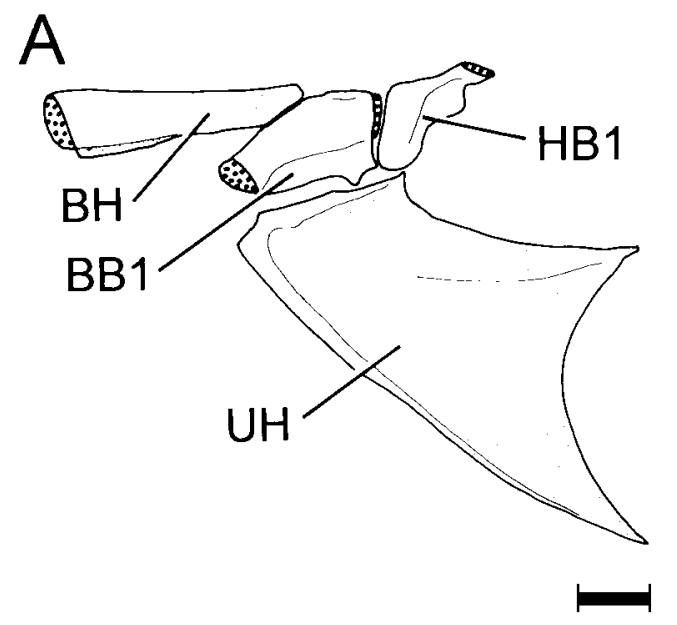

B

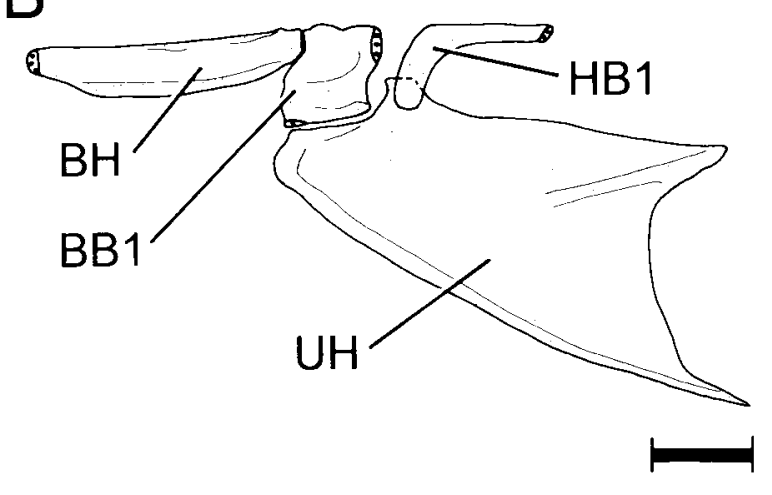

C

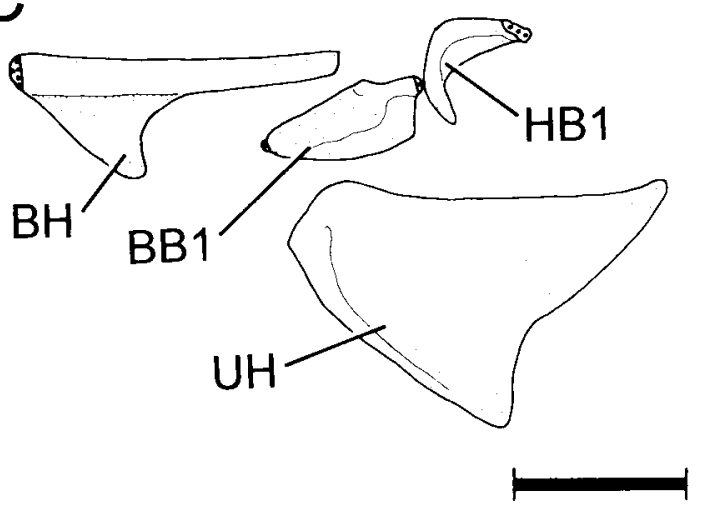

D

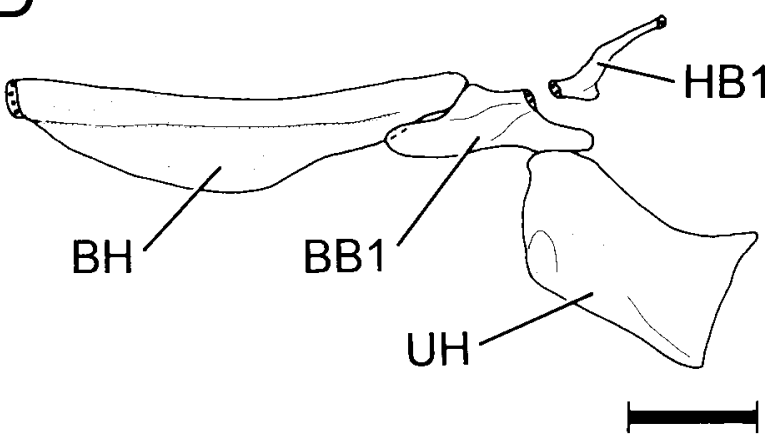

Figure 8. Right lateral view (reversed) of basihyal (BH), basibranchial 1 (BB1), hypobranchial 1 (HB1) and urohyal (UH) of selected pseudochromid species: A, Assiculus punctatus (Pseudochrominae), NTM S.10016-009, $32.2 \mathrm{~mm}$ SL; B, Chlidichthys johnvoelckeri (Pseudoplesiopinae), CAS 35451, $37.9 \mathrm{~mm}$ SL; C, Anisochromis kenyae (Anisochrominae), RUSI 4906, 23.3 mm SL; D, Blennodesmus scapularis (Congrogadinae), AMS I.26723-087, $49.7 \mathrm{~mm}$ SL. Cartilage shown in large stipple. Scale bars $=0.5 \mathrm{~mm}$. 
A

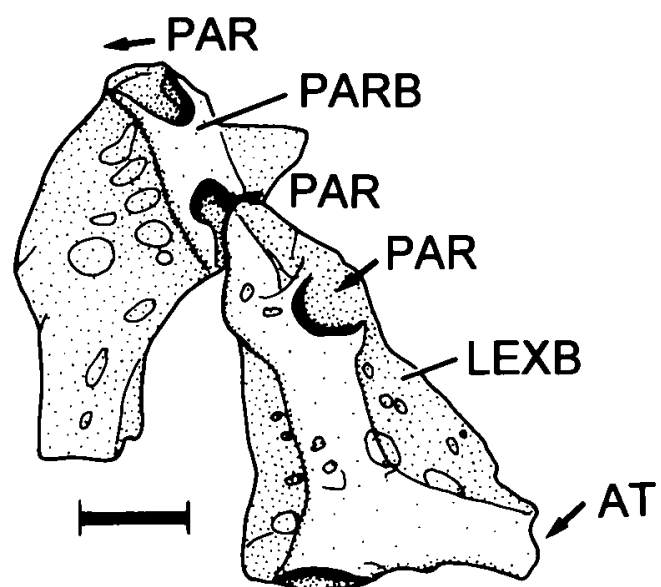

B

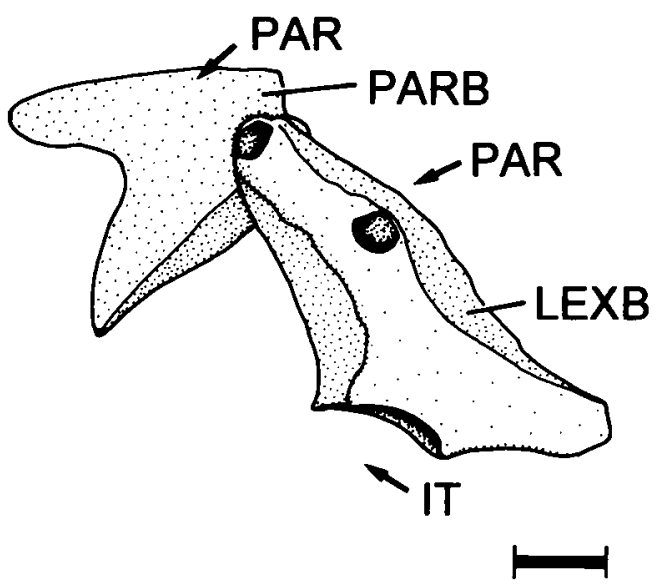

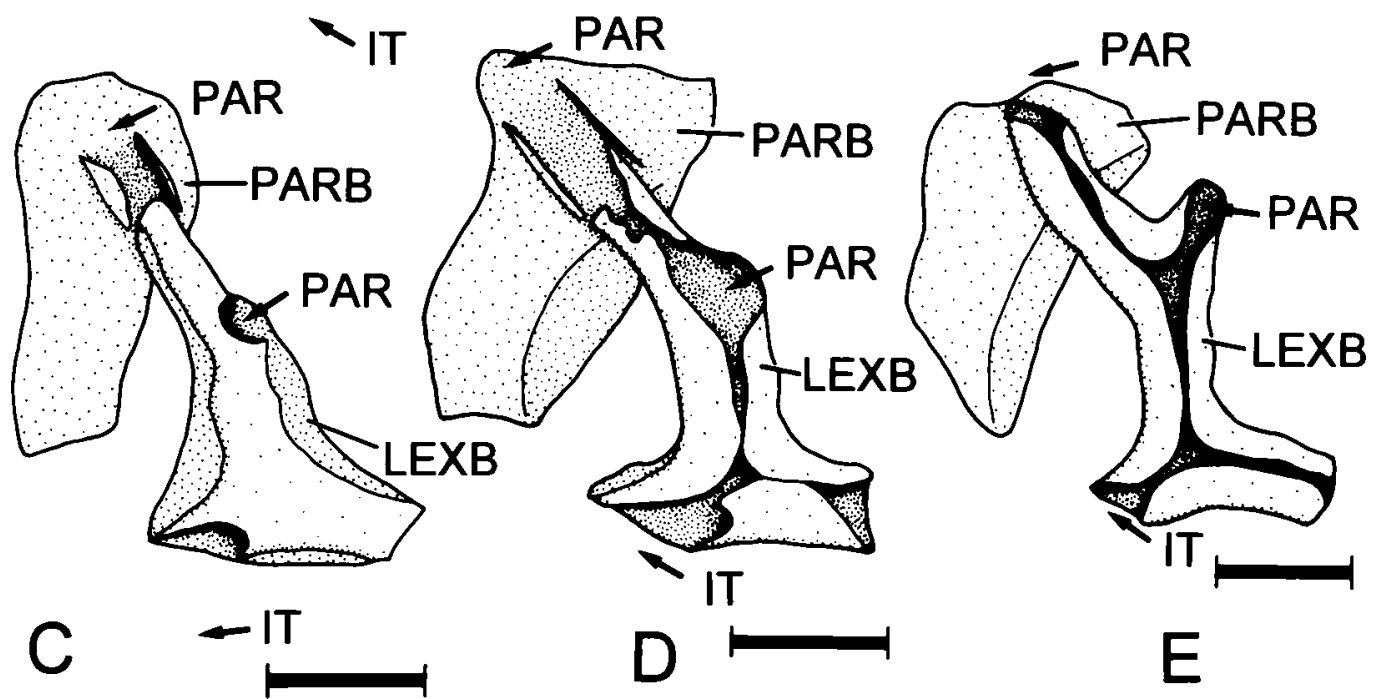

Figure 9. Lateral extrascapulae and parietal bones and associated laterosensory pores of selected pseudoplesiopine species: A, Lubbockichthys sp. 1, AMS I.25107-067, 47.3 mm SL; B, Pseudoplesiops typus, AMS I.19442-013, 50.6 mm SL; C, Amsichthys knighti, AMS I.22612-034, 28.3 mm SL; D, Chlidichthys johnvoelckeri, CAS 35451, 37.9 mm SL; E, Pectinochromis lubbocki, BPBM 28119, 35.5 mm SL (paratype). Arrows indicate locations of sensory pores. Abbreviations: AT, anterior temporal pore; IT, intertemporal pore; LEXB, lateral extrascapular bone; PAR, parietal pore; PARB, parietal bone. Scale bars $=0.5 \mathrm{~mm}$.

least as juveniles (state 0 ), as do pseudochromines and anisochromines and the vast majority of perciforms. Species of Lubbockichthys are unique among pseudoplesiopines in lacking cteni on body scales at all stages of ontogeny (state 1). The posterior body scales of congrogadines also lack cteni, as do those of some perciform taxa, such as ambassids, bathyclupeids, carangoids, cepolids, dinolestids, lactariids, leiognathids, opistognathids, sinipercids, clinids, dactyloscopids, zoarcoids, and most cirrhitoids (see Johnson, 1984: table 120; Roberts, 1993: appendix 1). Such scales have been generally termed "cycloid", but they are not homologous with the cycloid scales of lower teleosts (J. Radding, pers. comm.). Cteni are present in small (less than about $30 \mathrm{~mm} \mathrm{SL}$ ) specimens of Pseudoplesiops typus, but are absent from larger specimens; presumably cteni are either shed or, more likely, resorbed with growth. Other species of
Pseudoplesiops retain cteni on posterior body scales throughout ontogeny. We regard the condition found in Lubbockichthys as apomorphic and nonhomologous with that found in P. typus.

Character 9. Scales small. Chlidichthys, Amsichthys, Pectinochromis and Pseudoplesiops have relatively large to moderately small scales (state 0 ). In contrast, Lubbockichthys has relatively small scales (state 1). This character can be seen by differences in numbers of scales in lateral series (Table 2): 37-52 in Chlidichthys, 30-33 in Amsichthys, 35-39 in Pectinochromis and 26-42 in Pseudoplesiops, versus 5166 in Lubbockichthys. Most of the outgroup taxa have relatively large to moderately small scales. Scales in lateral series counts range from 39-44 in anisochromines, 35-42 in Assiculoides, and 38-46 in Assiculus. However, congrogadines also have numerous, small scales. Nevertheless, 


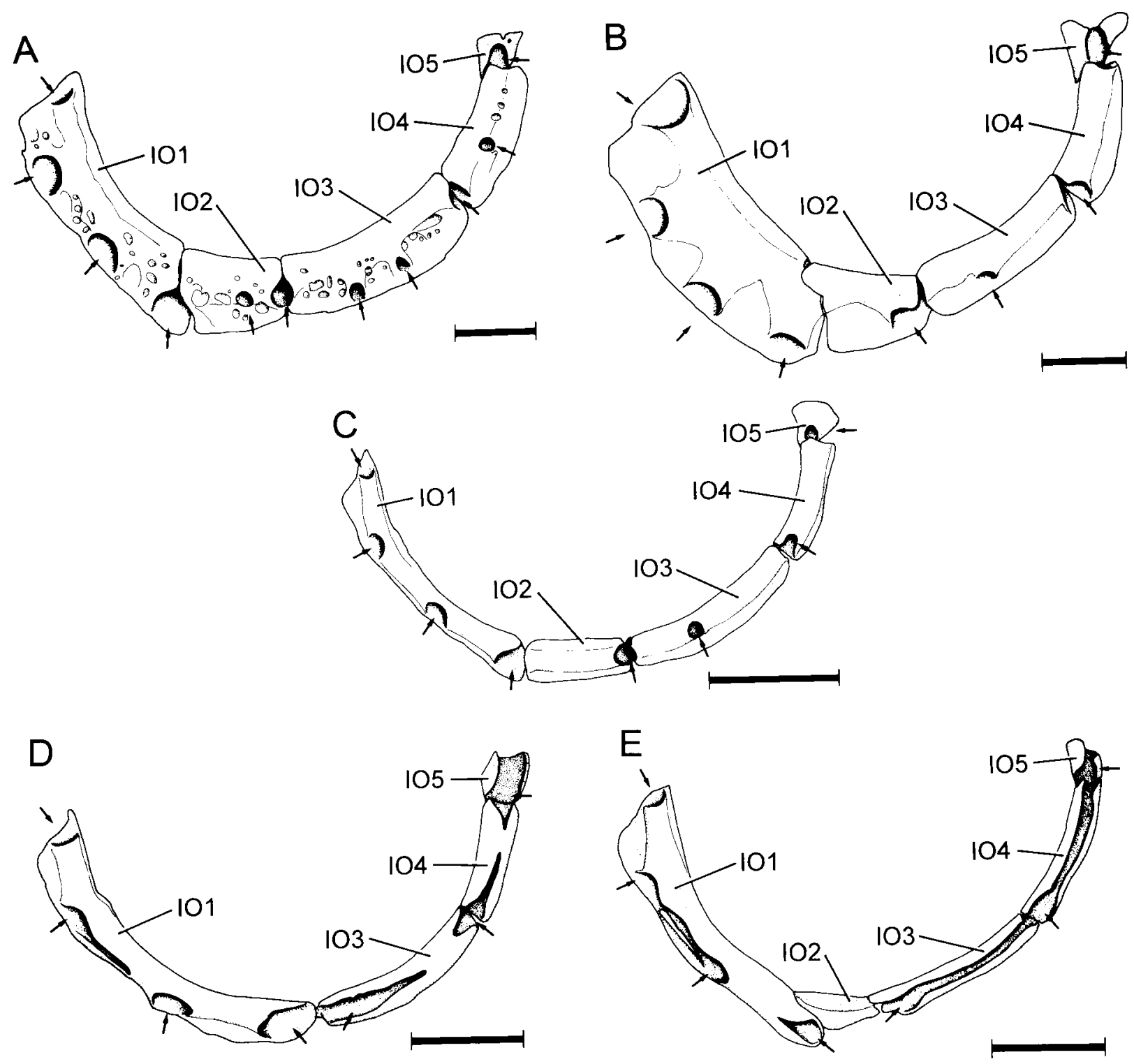

Figure 10. Infraorbital bones (IO1-5) of selected pseudoplesiopine species in left lateral view: A, Lubbockichthys sp. 1, AMS I.25107-067, 47.3 mm SL; B, Pseudoplesiops typus, ROM CS585, 49.0 mm SL; C, Amsichthys knighti, AMS I.22612-034, $28.3 \mathrm{~mm}$ SL; D, Chlidichthys johnvoelckeri, CAS 35451, $37.9 \mathrm{~mm}$ SL; E, Pectinochromis lubbocki, BPBM 28119, $35.5 \mathrm{~mm} \mathrm{SL}$ (paratype). Arrows indicate positions of suborbital pores. Scale bars $=1 \mathrm{~mm}$.

the condition shown by Lubbockichthys is most parsimoniously argued to be derived within the Pseudoplesiopinae.

Character 10. Some head bones with weakly honeycombed surface. Pseudoplesiops, Amsichthys, Pectinochromis and Chlidichthys have relatively smooth head bones (e.g., Figs. 9B-E, 10B-E; state 0), as do the outgroup taxa. Lubbockichthys has at least some head bones with a weakly honeycombed surface (e.g., Figs. 9A, 10A; state $1)$. We consider this condition to be apomorphic within the Pseudoplesiopinae.

Character 11. Medial laminae of pelvic bones expanded dorsally. The medial laminae (= inner wing of Stiassny \& Moore, 1992) of the pelvic bones of Lubbockichthys,
Amsichthys, Chlidichthys and Pectinochromis are at most weakly expanded dorsally, so that the pelvic bones have a concave to weakly convex dorsal profile (Fig. 11A; state 0$)$. The medial laminae of the pelvic bones of Pseudoplesiops are strongly expanded dorsally, so that the bones have a strongly convex dorsal profile (Fig. 11B; state 1). Anisochromines and the basal congrogadine genus Rusichthys have dorsally expanded medial laminae (with the exception of Halidesmus scapularis, more derived congrogadine genera lack dorsally expanded medial laminae, but this appears to be associated with reduction or loss of the pelvic fin), whereas Assiculoides and Assiculus (and all other pseudochromines) have weakly expanded laminae on the pelvic bones. Because both states occur in the outgroup taxa, this character was not polarised. 
Character 12. Loss of uppermost preopercular pore. Lubbockichthys, Pseudoplesiops, Pectinochromis and Chlidichthys and the outgroup taxa have the uppermost preopercular pore associated with the terminal opening in the preopercle (Fig. 12A,B,D,E; state 0). Amsichthys is distinctive in usually lacking a pore at the dorsal terminus of the preopercle (Fig. 12C; state 1). We consider the absence of the dorsal pore apomorphic. A terminal pore was present on one or both sides of the head of a few, relatively large specimens of Amsichthys; in contrast, a terminal pore was consistently present in juveniles and adults of the other pseudoplesiopine genera and in the outgroups. This suggests that the pore may develop relatively late in ontogeny in Amsichthys, in which case the character should be redescribed as delayed development of uppermost preopercular pore rather than loss of uppermost preopercular pore.

Character 13. Lower lip interrupted at symphysis. Amsichthys, Lubbockichthys, Pectinochromis, Pseudoplesiops, anisochromines, congrogadines, Assiculoides and Assiculus have the lower lip uninterrupted at the symphysis (Gill \& Randall, 1994: fig. 1A; Gill \& Hutchins, 1997: fig. 4; state 0). Chlidichthys species are unique among pseudoplesiopines in having the lower lip interrupted at the symphysis (Gill \& Randall, 1994: fig. 1B; state 1). We consider the latter condition apomorphic.

Character 14. First dorsal-fin pterygiophore expanded anteriorly. The anterior face of the first dorsal-fin pterygiophore is at best weakly expanded anteriorly in Chlidichthys, Amsichthys, Lubbockichthys and Pseudoplesiops (Fig. 13A$\mathrm{D}$; state 0). Pectinochromis is unusual in having the anterior part of the first dorsal-fin pterygiophore strongly expanded anteriorly (Fig. 13E; state 1). Anisochromines, Assiculoides and Assiculus have the anterior face of the first pterygiophore weakly expanded anteriorly; congrogadines lack the homologue of the first dorsal-fin pterygiophore (Gill, 1998). We therefore consider the condition shown by Pectinochromis apomorphic.

Character 15. First dorsal-fin pterygiophore with lateral processes. Chlidichthys, Amsichthys, Lubbockichthys and Pseudoplesiops lack lateral processes on the first dorsal-fin pterygiophore (Fig. 13A-D; state 0). Pectinochromis is distinctive in having prominent lateral processes on the first dorsal-fin pterygiophore (Fig. 13E; state 1). Anisochromines, Assiculoides and Assiculus lack such processes (and, as noted above, congrogadines lack the homologue of the first pterygiophore), and we therefore consider the condition shown by Pectinochromis apomorphic.

Character 16. Second dorsal-fin pterygiophore insertion between neural spines 2 and 3. Chlidichthys, Amsichthys, Lubbockichthys, Pseudoplesiops, anisochromines, Assiculus and Assiculoides have the first dorsal-fin pterygiophore insertion between neural spines 2 and 3, and the next two pterygiophores between neural spines 3 and 4 (Fig. 13AD; state 0). Congrogadines have only two dorsal-fin pterygiophores inserting anterior to neural spine 4, both positioned between neural spines 3 and 4, owing to the loss of the first pterygiophore (Gill, 1998). Pectinochromis has the first two pterygiophores between neural spines 2 and 3, and the third pterygiophore between neural spines 3 and 4 (Fig. 13E; state 1). The anterior position of the second pterygiophore is regarded as apomorphic.

Character 17. Dorsal fin anteriorly positioned. The dorsal-fin origin of Lubbockichthys, Pseudoplesiops, Amsichthys and Chlidichthys is near the vertical through the posterior edge of the operculum (Figs. 1-4, 12A-D; state 0), as it is in the outgroup taxa. Pectinochromis is unusual in having the dorsal-
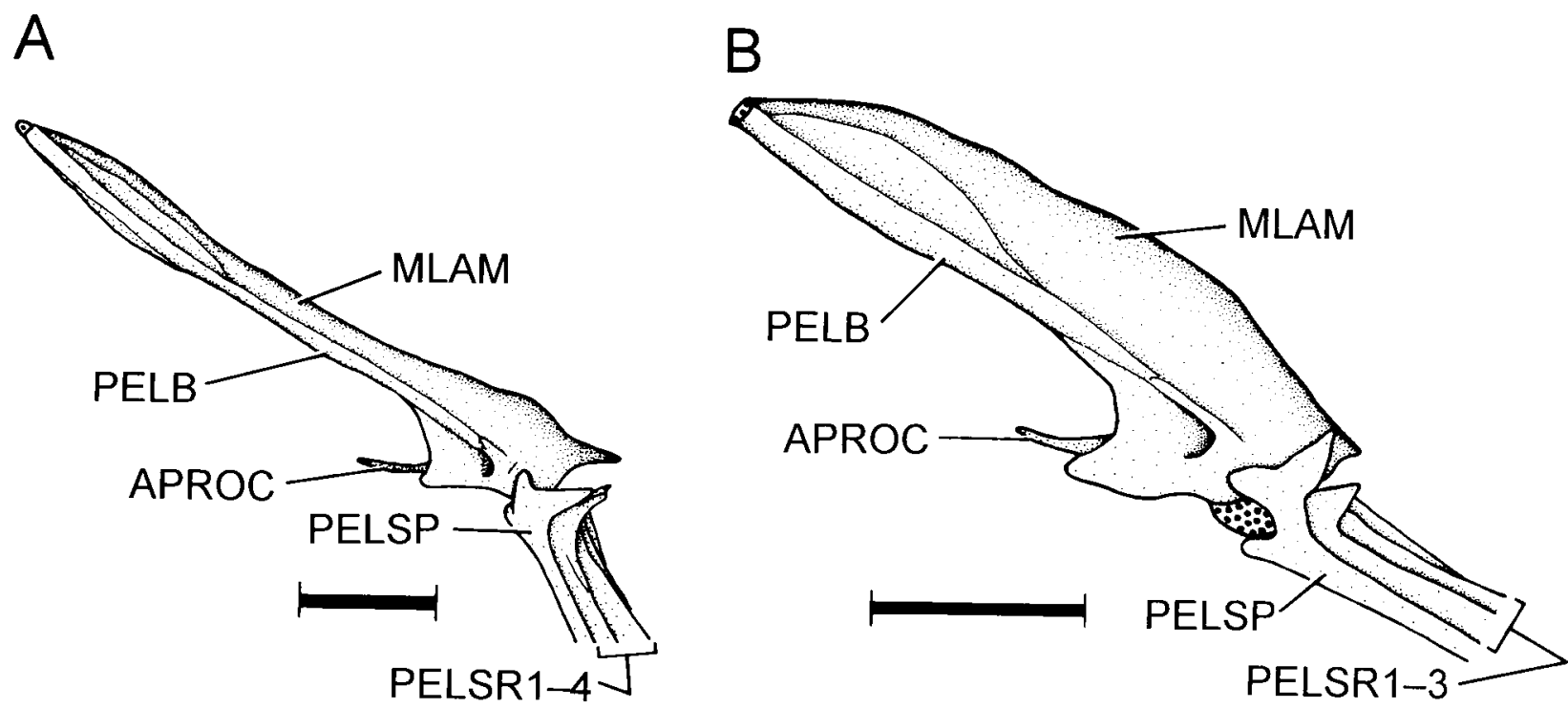

Figure 11. Right lateral view (reversed) of pelvic girdles of two pseudoplesiopine species: A, Amsichthys knighti, AMS I.22612-034, 28.3 mm SL; B, Pseudoplesiops rosae, AMS I.22582-073, $22.0 \mathrm{~mm}$ SL. Abbreviations as in Fig. 1. Cartilage shown in large stipple. Scale bars $=0.5 \mathrm{~mm}$. 

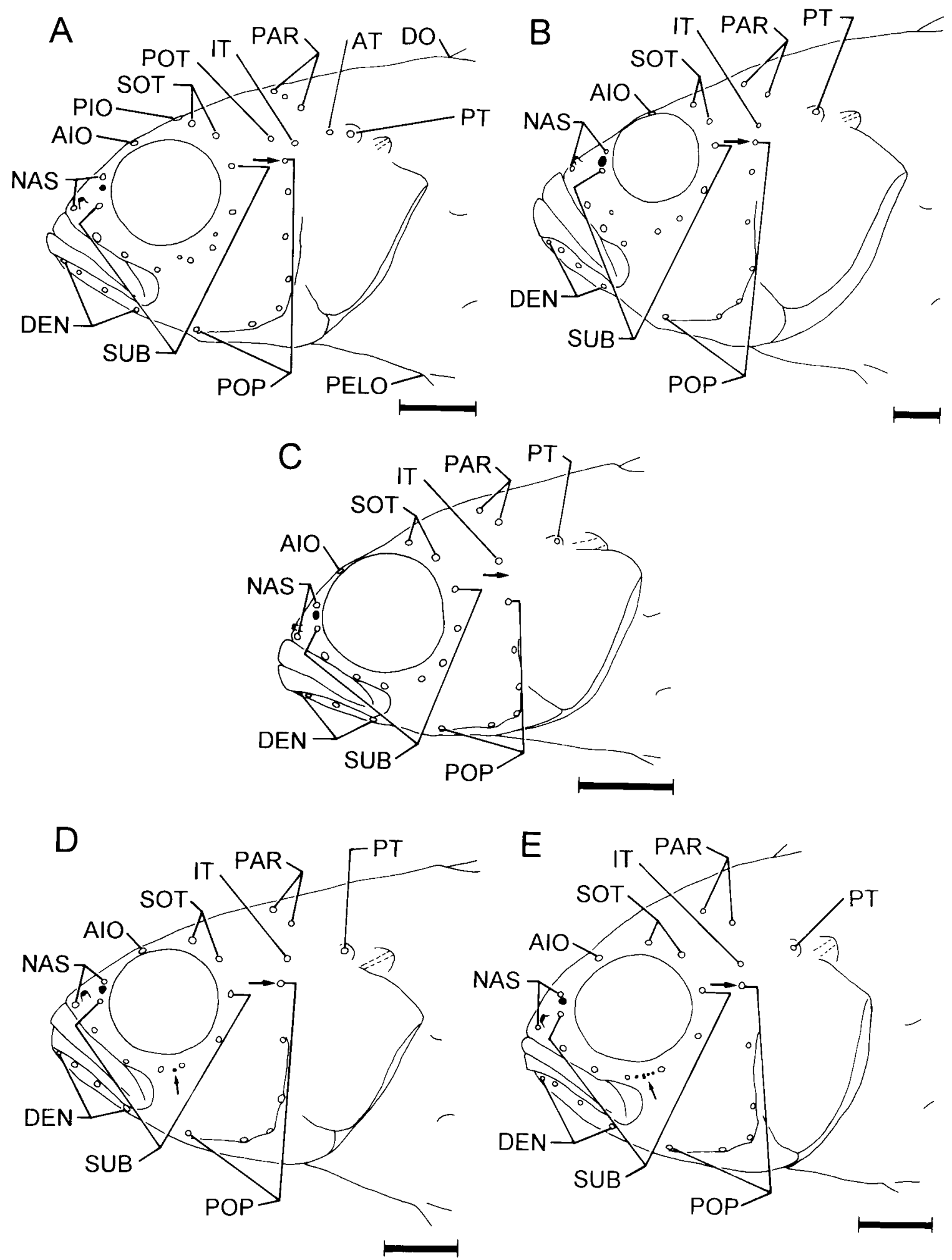

Figure 12. Left lateral diagrams of heads of selected pseudoplesiopine species: A, Lubbockichthys multisquamatus, AMS I.220779-175, 36.3 mm SL; B, Pseudoplesiops typus, WAM P.30842-019, 54.6 mm SL; C, Amsichthys knighti, NTM S.11384-018, 25.0 mm SL; D, Chlidichthys johnvoelckeri, ROM uncat., (field number RW 88-26), $36.2 \mathrm{~mm}$ SL; E, Pectinochromis lubbocki, BMNH 1982.6.9.1-4, $32.2 \mathrm{~mm}$ SL (paratype). Large arrow indicates dorsal tip of preopercle. Superficial neuromasts in D and E shown in black and indicated by small arrow. Abbreviations: AIO, anterior interorbital pore; AT, anterior temporal pore; DEN, dentary pores; DO, dorsal-fin origin; IT, intertemporal pore; NA, nasal pores; PLO, pelvic-fin origin; PAR, parietal pores; PIO, posterior interorbital pore; POP, preopercular pores; POT, posterior otic pore; PT, posttemporal pore; SOB, suborbital pores; SOT, supraotic pores. Scale bars $=2 \mathrm{~mm}$. 

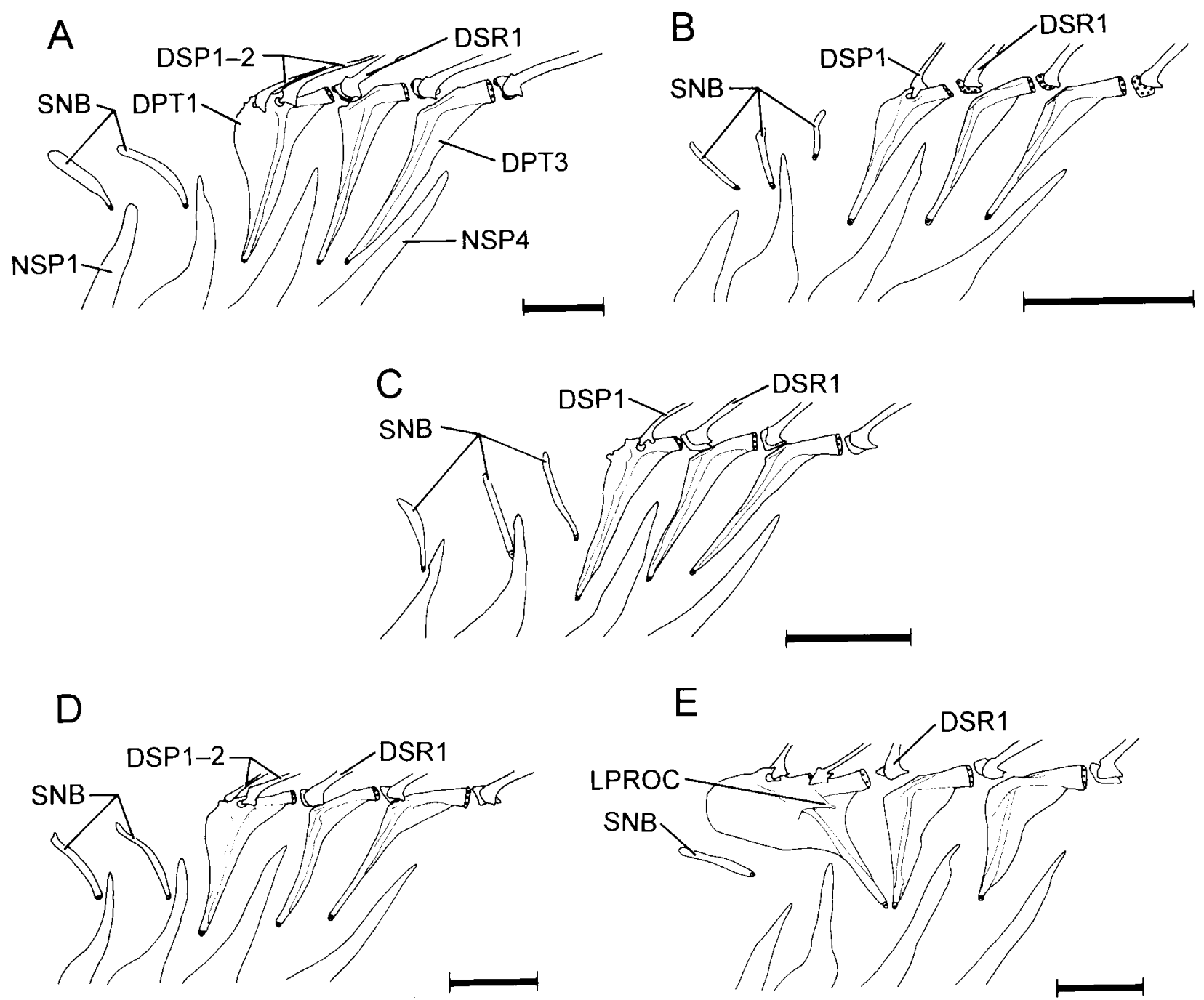

Figure 13. Anterior dorsal-fin pterygiophores and supraneural bones of selected pseudoplesiopine species in left lateral view: A, Lubbockichthys sp. 1, AMS I.25107-067, 47.3 mm SL; B, Pseudoplesiops howensis, AMS I.19755024, 21.0 mm SL; C, Amsichthys knighti, AMS I.22612-034, 28.3 mm SL; D, Chlidichthys johnvoelckeri, CAS 35451, $37.9 \mathrm{~mm}$ SL; E, Pectinochromis lubbocki, BPBM 28119, $35.5 \mathrm{~mm}$ SL (paratype). Cartilage shown in large stipple. Abbreviations: DPT1,3, dorsal-fin pterygiophores 1,3; DSP1-2, dorsal-fin spines 1-2; DSR1, segmented dorsal-fin ray 1; LPROC, lateral process on first dorsal-fin pterygiophore; NSP1,4, neural spines 1,4; SNB, supraneural bones. Scale bars $=1 \mathrm{~mm}$.

fin origin near the vertical through the preopercle (Figs. 5, 7E; state 1), a condition that we consider apomorphic.

Character 18. Single supraneural bone. Lubbockichthys, Pseudoplesiops, Amsichthys, Chlidichthys, Assiculoides, Assiculus and anisochromines have more than one supraneural bone (Fig. 13A-D; state 0). Pectinochromis has a single supraneural bone (Fig. 13E; state 1). Congrogadines have one to three tiny supraneural bones, varying considerably within species. We regard the single supraneural in Pectinochromis apomorphic.

Character 19. Numerous outer first-gill-arch rakers. Most pseudoplesiopines have relatively low to moderate numbers of total rakers on the outer face of the first gill arch: 12-16 for Amsichthys; 9-17 for Pseudoplesiops; 12-19 for Chlidichthys; and 12-21 for Lubbockichthys (state 0). The outgroup taxa have similar low to moderate numbers: 3-9 in anisochromines;
6-17 in congrogadines; 14-18 in Assiculoides; and 13-17 in Assiculus. Pectinochromis is distinctive in having numerous rakers on the outer face of the first arch, ranging from 27-31 (state 1). This state is regarded as apomorphic.

Character 20. Segmented pelvic-fin rays all unbranched. Adult specimens of Lubbockichthys have one or more segmented pelvic-fin rays branched (state 0). Chlidichthys, Amsichthys, Pectinochromis and Pseudoplesiops have all segmented pelvic-fin rays unbranched, (state 1). With the exception of some congrogadines that lack pelvic fins, the outgroup taxa have one or more branched segmented rays in the pelvic fin. The absence of branched rays is therefore regarded as apomorphic.

Character 21. Posterior otic pores absent. Adult specimens of Lubbockichthys have one or more posterior otic pores on each side of the head (Fig. 12A; state 0 ). The remaining 
pseudoplesiopine genera lack posterior otic pores (Fig. 12BE; state 1). Posterior otic pores are present in Assiculus, Assiculoides and anisochromines, and are either present (Halidesmus, Halimuraenoides and Congrogadus (Congrogadus)) or absent (Rusichthys, Haliophis, Natalichthys, Blennodesmus, Halimuraena and Congrogadus (Congrogadoides)) in congrogadines (Winterbottom, 1986, 1996; Winterbottom \& Randall, 1994). The lack of posterior otic pores is regarded as apomorphic within the Pseudoplesiopinae.

Character 22. Anterior temporal pores absent. Adult specimens of Lubbockichthys have an anterior temporal pore on each side of the head (Figs. 9A, 12A; state 0). The remaining pseudoplesiopine genera lack anterior temporal pores (Figs. 9B-E, 12B-E; state 1). Assiculus, Assiculoides, anisochromines and congrogadines possess anterior temporal pores; the absence of anterior temporal pores is therefore apomorphic within the Pseudoplesiopinae.

Character 23. Posterior interorbital pores. Adult specimens of Lubbockichthys have 1-2 (usually 1) median posterior interorbital pores on the head (Fig. 12A; state 0). The remaining pseudoplesiopine genera lack median posterior interorbital pores (Fig. 12B-E; state 1). Assiculoides and Assiculus lack median posterior interorbital pores. However, such pores are present in anisochromines and the majority of congrogadines. The polarity of this character within the Pseudoplesiopinae is, therefore, equivocal.

Character 24. Third supraneural bone well developed. The third supraneural bone is small or absent in Lubbockichthys, Pectinochromis, anisochromines, congrogadines, Assiculoides, Assiculus and all but one species of Chlidichthys (Fig. 13A,D,E; state 0). Amsichthys and all but a few relatively derived Pseudoplesiops species have the third supraneural bone well developed (Fig. 13B,C; state 1), a condition that we consider to be apomorphic. Chlidichthys abruptus is unique among pseudoplesiopines in exhibiting considerable intraspecific variation in this character; approximately one quarter of specimens examined lacked a third supraneural bone, whereas the remaining specimens had a weakly to well-developed third supraneural bone.

Character 25. Three epurals. Lubbockichthys, Amsichthys and Pseudoplesiops have two epurals (Fig. 14A-C; state 0), as do anisochromines, Assiculoides and basal congrogadines. Chlidichthys and Pectinochromis have three epurals (Fig. 14D,E; state 1). Assiculus and most of the remaining pseudochromines also have three epurals. [The exceptions, aside from Assiculoides, are members of the Pseudochromis tapeinosoma group (Gill \& Allen, 1996), which have two epurals.] Taken in the context of the scheme of outgroup relationships proposed herein, the three-epural state is most parsimoniously interpreted as apomorphic among pseudoplesiopines.

Character 26. Infraorbital 2 reduced or absent. In Lubbockichthys, Amsichthys and Pseudoplesiops, the infraorbital branch of the cephalic lateral-line systems passes through an uninterrupted series of canals in the five infraorbital bones (Fig. 10A-C; state 0). In Pectinochromis, infraorbital 2 is reduced in size and lacks a lateral-line canal, so that the canal passing through infraorbital 1 (lachrymal) does not communicate with the posterior series of canals (Fig. 10E; state 1). Infraorbital 2 is absent in Chlidichthys, giving a total of only four infraorbitals, and the canal passing through infraorbital 1 usually (see below) does not communicate with the posterior series of canals (Fig. 10D; state 2). The only Chlidichthys species in which there is communication between the anterior and posterior portions of the infraorbital canal (i.e., between infraorbitals 1 and 3) are the three members of a derived clade within the genus, $C$. cacatuoides, $C$. inornatus and $C$. rubiceps; we consider the uninterrupted series of infraorbitals in these species secondarily derived, and non-homologous with the outgroup condition. The outgroup taxa usually have the infraorbital branch of the cephalic lateral-line system passing through an uninterrupted series of canals in four (congrogadine genus Natalichthys), five (Assiculoides, anisochromines and most congrogadines) or six (Assiculus) infraorbital bones. (The noteworthy exception is the congrogadine genus Rusichthys, where only infraorbital bone 1 is present, and it does not communicate with the remainder of the cephalic lateral-line system.) Within the Pseudoplesiopinae, the reduction (through loss of the canal) and loss of infraorbital 2 are here regarded as an ordered transformation series. The reduction or loss of the second infraorbital in Pectinochromis and Chlidichthys is associated with the absence of a suborbital laterosensory pore that is present at the posterior opening of the second infraorbital in the remaining pseudoplesiopine genera. Instead, one or a series of superficial neuromasts are present between the tips of the first and third infraorbitals (Fig. 12D,E).

Character 27. Laterosensory-canal-bearing bones weakly developed. The laterosensory-canal-bearing bones of Lubbockichthys, Pseudoplesiops and Amsichthys are relatively well ossified, usually with well-developed laminar edges (Figs. 9A-C, 10A-C; state 0), as they are in the outgroup taxa (at least in adult specimens). In contrast, those of Chlidichthys and Pectinochromis are relatively weakly ossified, often with slit-like openings extending along the bones, and without well-developed laminar edges (Figs. 9D,E, 10D,E; state 1). We consider the latter apomorphic within the Pseudoplesiopinae.

Character 28. Second preopercular pore absent. Lubbockichthys has 6-11, rarely 6 (six only in small specimens) and Pseudoplesiops has 6-8, rarely 6 or 8 , preopercular pores, with the upper two pores relatively closely spaced (Fig. 12A,B; state 0). Pectinochromis and Chlidichthys usually have only six preopercular pores (occasional specimens of both genera may have seven pores on one or both sides, but the configuration of upper pores is the same as in specimens with six pores), with the upper pore well separated from the lower pores (Fig. 12D,E; state $1)$. The relatively low number of pores is here argued to have resulted from the loss of the homologue of the second pore of the seven-pored genera, which results in the upper two pores being well separated from each other. Amsichthys also usually has only six pores (Fig. 12C), but the arrangement is here argued to be non-homologous with that 

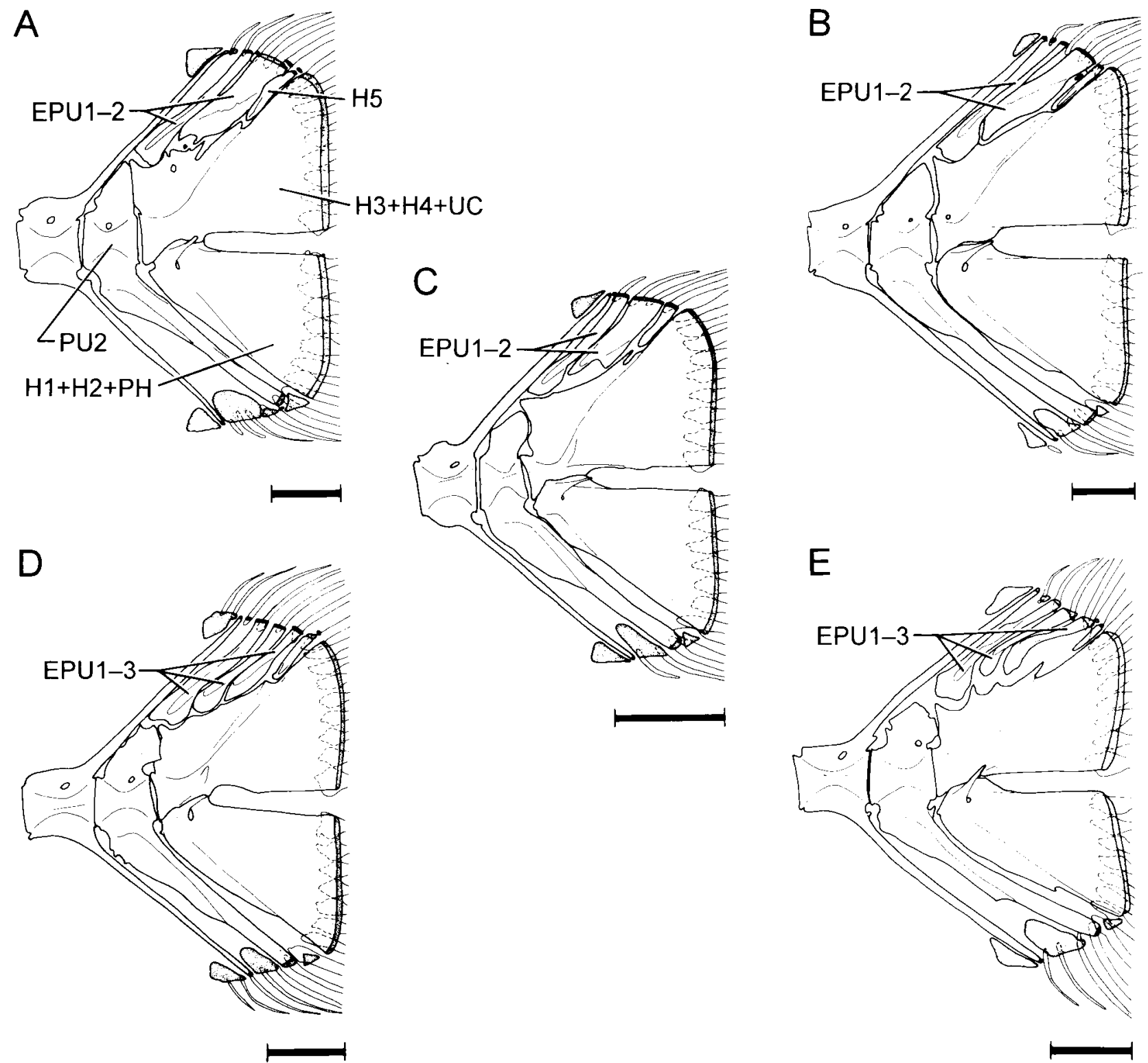

Figure 14. Caudal skeletons of selected pseudoplesiopine species in left lateral view: A, Lubbockichthys sp. 1, AMS I.25107-067, 47.3 mm SL; B, Pseudoplesiops typus, AMS I.19442-013, 50.6 mm SL; C, Amsichthys knighti, AMS I.22612-034, 28.3 mm SL; D, Chlidichthys johnvoelckeri, CAS 35451, 37.9 mm SL; E, Pectinochromis lubbocki, BPBM 28119, $35.5 \mathrm{~mm}$ SL (paratype). Cartilage shown in dense stipple; overlapping portions of fin-ray bases shown in broken lines. Abbreviations: EPU1-3, epurals $1-3 ; \mathrm{H} 1+\mathrm{H} 2+\mathrm{PH}$, fused hypurals 1 and 2 and parhypural; $\mathrm{H} 3+\mathrm{H} 4+\mathrm{UC}$, fused hypurals 3 and 4 and compound urostylar complex; H5, hypural 5; PU2, preural centrum 2. Scale bars $=1 \mathrm{~mm}$.

of Chlidichthys and Pectinochromis (see Character 12 above). The outgroup taxa have the upper two preopercular pores relatively close together, and most have relatively high numbers of preopercular pores: 12-16 for anisochromines; 10 19 for Assiculoides; and 9-18 for Assiculus. Congrogadines usually have only six or seven preopercular pores (nine in the relatively derived species Halidesmus polypterus), but the upper two pores are not widely separated. Therefore, the condition shown in Chlidichthys and Pectinochromis is considered apomorphic within the Pseudoplesiopinae.

Character 29. Ten precaudal vertebrae. Lubbockichthys,
Amsichthys and almost all Pseudoplesiops species have more than ten precaudal vertebrae (Table 2; state 0), as do most of the immediate outgroup taxa: 12-19 in congrogadines; 11-12 in Assiculoides; and 11 in Assiculus. Chlidichthys and Pectinochromis are unusual among pseudoplesiopines in having ten precaudal vertebrae (Table 2; state 1 ). Anisochromines, one relatively derived Pseudoplesiops species and most pseudochromines (the only exceptions are Assiculoides, Assiculus and Labracinus) also have ten precaudal vertebrae. However, parsimony dictates that the presence of ten precaudal vertebrae is apomorphic within the Pseudoplesiopinae. 
Character 30. Eye large. Most pseudoplesiopines have relatively small eyes: $8.5-10.6 \%$ SL in Chlidichthys, 7.9$11.7 \%$ SL in Lubbockichthys, and 8.2-11.0\% SL in Pseudoplesiops (state 0). Pectinochromis and Amsichthys are distinctive in having relatively large eyes, 10.5-11.9 and $9.9-12.5 \%$ SL, respectively (state 1); overlap with smaller-eyed taxa can largely be attributed to ontogenetic variation (smaller specimens have proportionally larger eyes). Outgroup taxa have relatively small to moderate eyes; the condition shown by Amsichthys and Pectinochromis is therefore considered apomorphic.

Character 31. Dorsal-fin-ray branching. Pseudoplesiops, Amsichthys and Chlidichthys have mostly simple (unbranched) segmented dorsal-fin rays (state 0). Lubbockichthys and Pectinochromis have mostly branched segmented dorsalfin rays (state 1). The first outgroup has mostly branched rays in this fin, whereas the second and third outgroups have mostly simple rays in the dorsal fin. Polarisation of this character is therefore equivocal within the Pseudoplesiopinae.

Character 32. Segmented anal-fin rays mostly simple. Lubbockichthys and Pectinochromis have mostly branched segmented anal-fin rays, as do the outgroup taxa (state 0). Conversely, the remaining pseudoplesiopine genera have mostly simple segmented anal-fin rays (state 1). The latter condition is therefore apomorphic within the subfamily.

Results of Parsimony Analysis. Phylogenetic analysis of the 32 characters (Table 1) resulted in the single tree shown in Fig. 15: tree length $=36$; consistency index $=0.91$; retention index $=0.76$. [A second analysis was also performed using only characters $20-32$, with character 26 recoded as " 1 " for Chlidichthys. In so doing, untested characters (synapomorphies of the Pseudoplesiopinae, and unique, unequivocal generic autapomorphies) were excluded. The analysis yielded the same tree, with the following statistics: tree length $=16$; consistency index $=$ 0.81 ; retention index $=0.76$.] .

Characters supporting monophyly of the Pseudoplesiopinae and its genera are discussed above in the diagnoses for the respective taxa.

Three synapomorphies support monophyly of a clade consisting of Chlidichthys, Amsichthys, Pectinochromis and Pseudoplesiops: segmented pelvic-fin rays all unbranched (character 20); posterior otic pores absent (character 21); and anterior temporal pores absent (character 22). One additional character, posterior interorbital pores (character 23), either supports monophyly of the clade (state 1), or is an autapomorphy of Lubbockichthys (state 0); the equivocal nature results from the presence of both states in the outgroup taxa (state 0 in the first outgroup, state 1 in the second and third outgroups), and the basal position of Lubbockichthys within the Pseudoplesiopinae. Similarly, mostly unbranched anal-fin rays (character 32) and mostly unbranched dorsal-fin rays (character 31 ), provide equivocal support for the clade consisting of Chlidichthys, Amsichthys, Pectinochromis and Pseudoplesiops (see below).

A single synapomorphy supports a sister-group relationship between Amsichthys and Pseudoplesiops: third supraneural bone well developed (character 24). However, as this character varies within Pseudoplesiops, and is intraspecifically variable in C. abruptus, support for this relationship is weak. The distribution of one other character, segmented anal-fin rays mostly simple (character 32), is equivocal; it either supports monophyly of Amsichthys + Pseudoplesiops (and occurs homoplastically in Chlidichthys), or diagnoses the more general clade that also includes Chlidichthys and Pectinochromis, with autapomorphic reversal in the latter genus. Mostly unbranched dorsal-fin rays (character 31) provides similar equivocal support for a sister relationship between Amsichthys and Pseudoplesiops (see below).

Five synapomorphies support a sister-group relationship between the Indian Ocean taxa Chlidichthys and Pectinochromis: three epurals (character 25); infraorbital 2 reduced or absent (character 26); laterosensory-canal-bearing bones weakly developed (character 27); second preopercular pores absent (character 28); and ten precaudal vertebrae (character 29).

Character 30-eyes large-is most parsimoniously interpreted as independently derived autapomorphies of Pectinochromis and Amsichthys.

The presence of mostly unbranched segmented dorsalfin rays (character 31 ) has been cited as an autapomorphy of the Pseudoplesiopinae (Smith, 1954; Springer et al.,

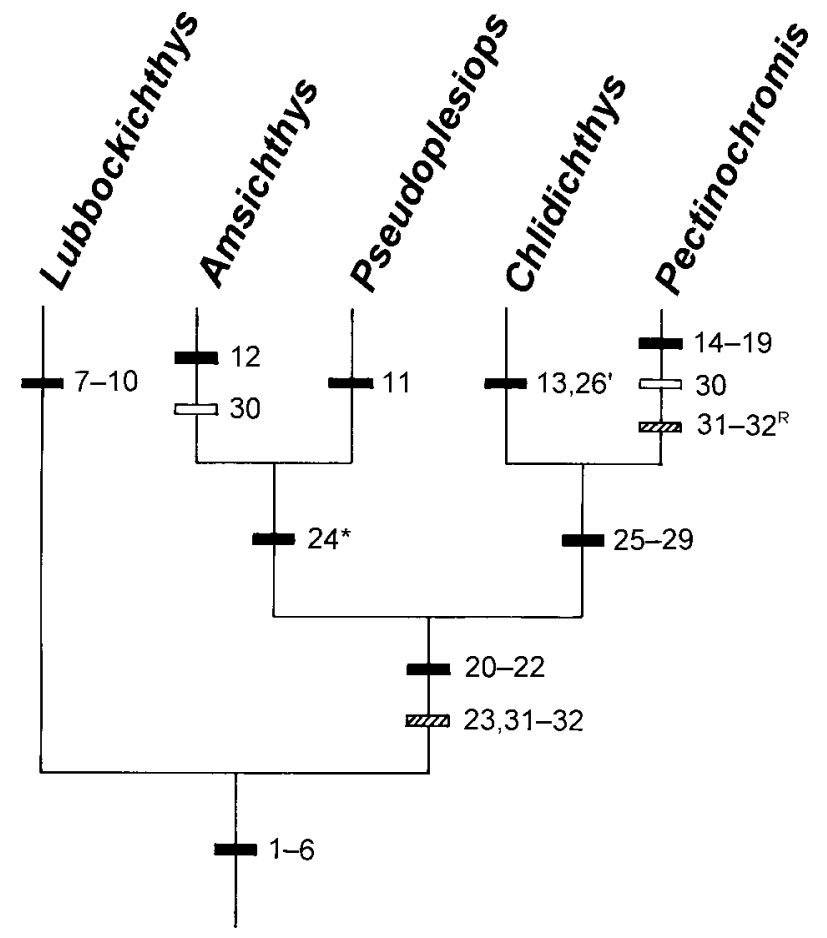

Figure 15. Cladogram of relationships between pseudoplesiopine genera generated from matrix in Table 1. Numbers indicate characters that support relationships (see text for details): solid bars indicate uncontradicted synapomorphies; open bars indicate homoplastic characters with unequivocal optimisations; hatched bars indicate homoplastic characters with equivocal distributions (see text for alternative optimisations); $\mathrm{R}$ indicates characters that reverse; * indicates characters that reverse within some derived (non-basal) species in terminal taxa; ' indicates derived state of multistate character. 
Table 2. Comparison of selected characters of pseudoplesiopine genera. * Anterior extent of predorsal scalation is expressed in terms of proximity of anterior edge of first scale to either interorbital or supratemporal laterosensory commissure.

\begin{tabular}{|c|c|c|c|c|c|c|c|c|}
\hline 坅 & 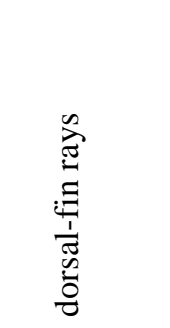 & 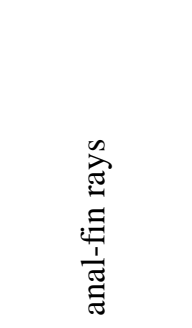 & 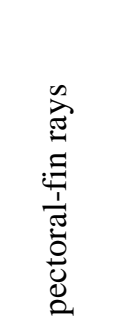 & 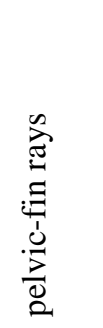 & 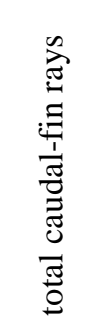 & $\begin{array}{l}\frac{\pi}{0} \\
\stackrel{0}{0} \\
\stackrel{0}{0} \\
\stackrel{0}{0}\end{array}$ & 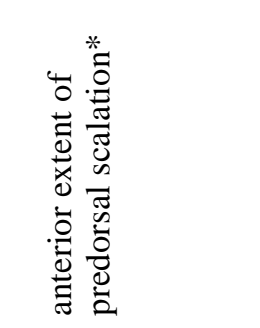 & 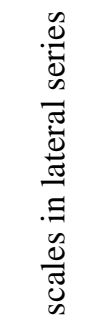 \\
\hline Amsichthys & I,23-24 & I-II,13-15 & $16-18$ & $\mathrm{I}, 4$ & $24-25$ & $11+18$ & interorbital & $30-33$ \\
\hline Chlidichthys & II, 21-24 & II-III, 12-15 & $16-19$ & $\mathrm{I}, 4$ & $25-29$ & $10+17-19$ & $\begin{array}{l}\text { supratemporal to } \\
\text { interorbital }\end{array}$ & $37-52$ \\
\hline Lubbockichthys & II,24-26 & II, 14-16 & $16-19$ & $\mathrm{I}, 4$ & $24-27$ & $12-14+17-19=30-32$ & supratemporal & $51-66$ \\
\hline Pectinochromis & II, 22-23 & II, $12-13$ & $16-17$ & $\mathrm{I}, 4$ & $22-24$ & $10+16-17$ & interorbital & $35-39$ \\
\hline Pseudoplesiops & I-II, 22-29 & I-III,13-18 & $15-18$ & $\mathrm{I}, 3-4$ & $23-26$ & $10-14+17-21=28-33$ & $\begin{array}{l}\text { supratemporal to } \\
\text { interorbital }\end{array}$ & $26-42$ \\
\hline
\end{tabular}

1977; Godkin \& Winterbottom, 1985). However, the present analysis reveals that this character is homoplastic, with both character states occurring within the subfamily and its immediate outgroups. There are three equally parsimonious optimisations of the character, none of which provides support for monophyly of the Pseudoplesiopinae: (1) rays mostly branched (state 1) a synapomorphy of the Anisochrominae + Congrogadinae + Pseudoplesiopinae clade, with reversal to mostly unbranched rays (state 0 ) in the clade consisting of Amsichthys, Chlidichthys, Pectinochromis and Pseudoplesiops, and autapomorphic acquisition of mostly branched rays in Pectinochromis (accelerated transformation optimisation); (2) independent acquisition of branched rays in Anisochrominae + Congrogadinae, Lubbockichthys and Pectinochromis (delayed transformation optimisation); and (3) mostly branched rays a synapomorphy of the Anisochrominae + Congrogadinae + Pseudoplesiopinae clade, with independent reversal to mostly unbranched rays in Chlidichthys and in the clade consisting of Pseudoplesiops and Amsichthys.

ACKNOWLEDGMENTS. We thank the following for the loan of specimens for this paper: J.T. Williams, S. Jewett (USNM), H.K. Larson (NTM), M. McGrouther, S.E. Reader, T. Trnksi (AMS), P.C. Heemstra (RUSI), J.E. Randall, A. Suzumoto (BPBM), D. Catania, W.N. Eschmeyer (CAS); W. Saul (ANSP), R. Winterbottom, M. Rouse (ROM); G.R. Allen, J.B. Hutchins, S. Morrison (WAM). S. Davidson and A.-M. Hine assisted with radiography and clearing and staining of specimens. P. Crabb photographed the specimens in Figs. 1-5. M.P.J. van Oijen provided a translation of Bleeker's description of Pseudoplesiops typus. G.D. Johnson, R.D. Mooi, J. Radding, D.J. Siebert, V.G. Springer, and R. Winterbottom discussed various aspects of this study. Manuscript drafts were read by, and improved by helpful comments from J.M. Leis, R.D. Mooi, N.R. Merrett and two anonymous reviewers.

\section{References}

Allen, G.R., 1987. Descriptions of three new pseudochromid fishes of the genus Pseudoplesiops from Australia and surrounding regions. Records of the Western Australian Museum 13(2): 249-261.
Berg, L.S., 1940. Classification of fishes both Recent and fossil. Travaux de l'Institut Zoologique de l'Akadémie des Sciences de l'URSS 5(2): 87-517.

Bleeker, P., 1858. Bijdrage tot de kennis der vischfauna van den Goram Archipel. Naturrkundig Tijdschrift Nederlandsch Indië 15: 197-218.

Bleeker, P., 1875. Sur la famille des Pseudochromoïdes et révision de ses espéces insulindiniennes. Verhandelingen der Koninklijke Akademie van Wetenschappen, Amsterdam 15: 1-32, pls 1-3.

Boulenger, G.A., 1895. Catalogue of the Perciform Fishes in the British Museum. Second Edition. Volume 1. London: Trustees of the British Museum.

Boulenger, G.A., 1899. Matériaux pour la fauna du Congo. Cinquième Partie. Cyprins, Silures, Cyprinodontes, Acanthoptérygiens. Annales du Musée du Congo, ser. zool. 1: 97-128, pls 40-47.

Boulenger, G.A., 1901. Notes on the classification of teleostean fishes.- I. On the Trachinidae and their allies. Annals and Magazine of Natural History (7) 8: 261-271.

Boulenger, G.A., 1902. Contributions to the ichthyology of the Congo.--II. On a collection of fishes from the Lindi River. Proceedings of the Zoological Society of London 1902(1): 265-271, pls 28-30.

Böhlke, J.E., 1960. Comments on serranoid fishes with disjunct lateral lines, with the description of a new one from the Bahamas. Notulae Naturae of the Academy of Natural Sciences of Philadelphia 330: 1-11.

Dingerkus, G., \& L.D. Uhler, 1977. Enzyme clearing of alcian blue stained whole vertebrates for demonstration of cartilage. Stain Technology 52: 229-232.

Edwards, A.J., \& J.E. Randall, 1983. A new dottyback of the genus Pseudoplesiops (Teleostei: Perciformes: Pseudochromidae) from the Red Sea. Revue Française d'Aquariologie Herpétologie 9(4): 111-114.

Farris, J.S., 1988. "Hennig86, Version 1.5," Program and documentation. New York: Farris, Port Jefferson.

Fowler, H.W., 1931. Contributions to the biology of the Philippine Archipelago and adjacent regions. The fishes of the families Pseudochromidae, Lobotidae, Pempheridae, Priacanthidae, Lutjanidae, Pomadasyidae, and Theraponidae, collected by the United States Bureau of Fisheries steamer "Albatross", chiefly in Philippine seas and adjacent waters. United States National Museum Bulletin 100(11): 1-388.

Fowler, H.W., 1934. Descriptions of new fishes obtained 1907 to 1910, chiefly in the Philippine Islands and adjacent seas. 
Proceedings of the Academy of Natural Sciences Philadelphia 85: 354-357.

Gill, A.C., 1998. Homology of the anterior vertebrae, ribs, and dorsal fin pterygiophores and rays in congrogadine fishes (Perciformes: Pseudochromidae). Copeia 1998(4): 1041-1045.

Gill, A.C., \& G.R. Allen, 1996. Pseudochromis viridis, a new species of dottyback from Christmas Island, Indian Ocean (Teleostei: Perciformes: Pseudochromidae). Revue Française d'Aquariologie Herpétologie 23(1-2): 33-38.

Gill, A.C., \& J.B. Hutchins, 1997. Assiculoides desmonotus, new genus and species of dottyback from the Kimberley coast of Western Australia (Teleostei: Perciformes: Pseudochromidae). Revue Française d'Aquariologie Herpétologie 24(1-2): 43-48.

Gill, A.C., \& R.D. Mooi, 1993. Monophyly of the Grammatidae and of the Notograptidae, with evidence for their phylogenetic positions among perciforms. Bulletin of Marine Science 52(1): 327-350.

Gill, A.C., \& J.E. Randall, 1994. Chlidichthys cacatuoides, a new species of pseudoplesiopine dottyback from southern Oman, with a diagnosis of the genus Chlidichthys Smith, and new record of Pseudochromis punctatus Kotthaus from Oman (Teleostei: Perciformes: Pseudochromidae). Revue Française d'Aquariologie Herpétologie 21(1-2): 11-18.

Gill, A.C., J.E. Randall \& A.J. Edwards, 1991. Pseudoplesiops collare, a new species of fish from Indonesia, with lectotype designation for Nematochromis annae Weber (Perciformes: Pseudochromidae: Pseudoplesiopinae). Revue Française d'Aquariologie Herpétologie 18(3): 75-78.

Godkin, C.M., \& R. Winterbottom, 1985. Phylogeny of the family Congrogadidae (Pisces; Perciformes) and its placement as a subfamily of the Pseudochromidae. Bulletin of Marine Science 36(3): 633-671.

Günther, A., 1860. Catalogue of the Acanthopterygian Fishes in the Collection of the British Museum. Volume second. Squamipinnes, Cirrhitidae, Triglidae, Trachinidae, Sciaenidae, Polynemidae, Sphyraenidae, Trichiuridae, Scombridae, Carangidae, Xiphiidae. London: Trustees of the British Museum.

International Commission on Zoological Nomenclature, 1986. Opinion 1417. Chromis Cuvier in Desmarest, 1814 (Osteichthyes, Perciformes): gender confirmed as feminine. Bulletin of Zoological Nomenclature 43(3): 267-268.

Johnson, G.D., 1984. Percoidei: development and relationships. In Ontogeny and Systematics of Fishes, eds. H.G. Moser, W.J. Richards, D.M. Cohen, M.P. Fahay, A.W. Kendall Jr. \& S.L. Richardson, pp. 464-498. American Society of Ichthyologists and Herpetologists Special Publication No. 1. Lawrence: Allen Press.

Jordan, D.S., 1923. A classification of fishes including families and genera as far as known. Stanford University Publications, University Series, Biological Sciences 3(2): 77-243+i-x.

Leviton, A.E., R.H. Gibbs Jr., E. Heal \& C.E. Dawson, 1985. Standards in herpetology and ichthyology: part 1. Standard symbolic codes for institutional resource collections in herpetology and ichthyology. Copeia 1985(3): 802-832.

Lubbock, R., 1975. Fishes of the family Pseudochromidae (Perciformes) in the northwest Indian Ocean and Red Sea. Journal of Zoology, London 176: 115-157.

Lubbock, R., 1976. Fishes of the family Pseudochromidae (Perciformes) in the central Indian Ocean. Journal of Natural History 10: 167-177.

Lubbock, R., 1977. Fishes of the family Pseudochromidae (Perciformes) in the western Indian Ocean. Ichthyological Bulletin of the J.L.B. Smith Institute of Ichthyology 35: 1-21, pls 1-5.

McAllister, D.E., 1968. Evolution of branchiostegals and classification of teleostome fishes. National Museum of Canada Bulletin 221: 1-239.

Mooi, R.D., 1993. Phylogeny of the Plesiopidae (Pisces: Perciformes: Percoidei) with evidence for the inclusion of the Acanthoclinidae. Bulletin of Marine Science 52(1): 284-326.
Mooi, R.D., [1996]. Revision, phylogeny, and discussion of biology and biogeography of the fish genus Plesiops (Perciformes: Plesiopidae). Royal Ontario Museum Life Science Contributions 159: 1-108. [Publication dated 1995, but actually published January 1996.]

Norman, J.R., 1966. A Draft Synopsis of the Orders, Families and Genera of Recent Fishes and Fish-like Vertebrates. London: Trustees of the British Museum (Natural History).

Pellegrin, J., 1904. Contribution á l'étude anatomique, biologique et taxinomique des poissons de la famille des Cichlidés. Mémoires de la Société Zoologique de France 16(3-4): 41-400, pls 4-7.

Potthoff, T., 1984. Clearing and staining techniques. In Ontogeny and Systematics of Fishes, eds. H.G. Moser, W.J. Richards, D.M. Cohen, M.P. Fahay, A.W. Kendall Jr. \& S.L. Richardson, pp. 3537. American Society of Ichthyologists and Herpetologists Special Publication No. 1. Lawrence: Allen Press.

Regan, C.T., 1913. The classification of the percoid fishes. Annals and Magazine of Natural History (8)12: 111-145.

Roberts, C.D., 1993. Comparative morphology of spined scales and their phylogenetic significance in the Teleostei. Bulletin of Marine Science 52(1): 60-113.

Schultz, L.P., 1943. Fishes of the Phoenix and Samoan Islands collected in 1939 during the expedition of the U.S.S. "Bushnell." United States National Museum Bulletin 180: 1316.

Schultz, L.P., 1953. Family Pseudochromidae, pp. 380-411, pl. 33a. In: Schultz, L.P., E.S. Herald, E.A. Lachner, A.D. Welander \& L.P. Woods, Fishes of the Marshall and Marianas Islands. Volume 1. Families from Asymmetrontidae through Siganidae. United States National Museum Bulletin 202: 1-685.

Smith, J.L.B., 1953. The Sea Fishes of Southern Africa. Third Edition. Cape Town: Central News Agency Ltd.

Smith, J.L.B., 1954. Pseudoplesiopsine fishes from South and East Africa. Annals and Magazine of Natural History (12)7: 195-208.

Springer, V.G., C.L. Smith \& T.H. Fraser, 1977. Anisochromis straussi, new species of protogynous hermaphroditic fish, and synonymy of Anisochromidae, Pseudoplesiopidae, and Pseudochromidae. Smithsonian Contributions to Zoology 252: 1-15.

Stiassny, M.L.J., \& J.A. Moore, 1992. A review of the pelvic girdle of acanthomorph fishes, with comments on hypotheses of acanthomorph intrarelationships. Zoological Journal of the Linnean Society 104: 209-242.

Taylor, W.R., 1967. An enzyme method of clearing and staining small vertebrates. Proceedings of the United States National Museum 122: 1-17.

Weber, M., 1913. Die Fische Der Siboga-expedition. Siboga Expeditie LVII. Leiden: E.J. Brill.

Weber, M., \& L.F. de Beaufort, 1929. The Fishes of the IndoAustralian Archipelago. V. Leiden: E.J. Brill.

Weber, M., \& L.F. de Beaufort, 1931. The Fishes of the IndoAustralian Archipelago. VI. Leiden: E.J. Brill.

Winterbottom, R., [1986]. Revision and vicariance biogeography of the subfamily Congrogadinae (Pisces: Perciformes: Pseudochromidae). Indo-Pacific Fishes 9: 1-34, pl. 1. [Publication dated 1985, but actually published February, 1986.]

Winterbottom, R., 1996. A new species of the congrogadin genus Rusichthys from southern Oman (Perciformes; Pseudochromidae), with notes on its osteology. Canadian Journal of Zoology 74(3): 581-584.

Winterbottom, R., \& J.E. Randall, 1994. Two new species of congrogadins (Teleostei; Pseudochromidae), with range extensions for four other species. Canadian Journal of Zoology 72(4): 750-756.

Manuscript received 13 July 1998, revised 11 February 1999 and accepted 4 March 1999.

Associate Editor: J.M. Leis 